

\section{QM555 \\ Ar 3 \\ Columbia ffrúbersity cop.2 in the City of 羽ew 侽ork}

School of 㚼ental and Oral Surgeny

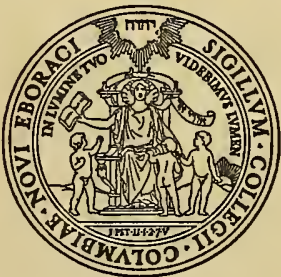

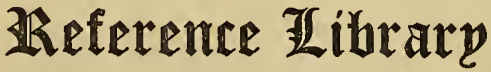





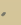





\title{
A LABORATORY GUIDE
}

\author{
IN \\ HISTOLOGY
}

By

LESLIE BRAINERD AREY, Рн.D.

Associate Professor of Anatomy in the Northwestern

University Medical School

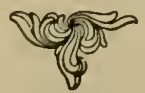

PHILADELPHIA AND LONDON

W. B. SAUNDERS COMPANY

I9I 7 
Copyright, I9 1 7, by W. B. Saunders Company

$$
\begin{aligned}
& \text { QM555 } \\
& \text { Fis }
\end{aligned}
$$




\section{PREFACE.}

THE purpose of this book is to furnish laboratory instructions adapted for use in any standard course of normal Histology. With the exception of gross anatomy, no laboratory subject today enjoys more uniformity of presentation than does Histology. In the study of the fundamental tissues greater flexibility of treatment exists than in the microscopic anatomy of organs, yet in both definite routine structures must be observed and their inter-relations and significance emphasized. For this reason it is hoped that a laboratory guide designed to accomplish these ends, without reference to the peculiarities of any particular course, may prove useful.

For the most part, directions involving fresh tissues and organs, or specially stained and treated preparations, illustrative of uncommon features, have been omitted. This is done not with the intention of minimizing their importance, but because it is in these minutiæ that courses vary most.

An attempt has been made to put the treatment throughout on an inductive basis. Rather than presenting a mere list of structures to be identified, in so far as is practicable, the student is led to scrutinize, explain, and reach independent conclusions. The frequent interjection of appropriate queries should relieve the instructor of much tedious and often belated individual quizzing and directing.

L. B. A.

Chicago, Ill.

August, 1917. 
Digitized by the Internet Archive in 2010 with funding from Columbia University Libraries 


\section{CONTENTS.}

PAGE

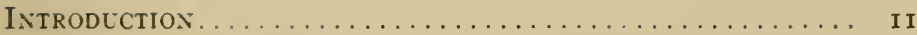

PART 1.-CYTOLOGY.

CHAPTER I.

The Cell and Cell Division................. I4

Resting Cell, $\mathrm{r}_{4}$; Amitosis, $\mathrm{r}_{5}$; Mitosis, $\mathrm{r}_{5}$.

PART II.-HISTOLOGY.

CHAPTER II.

The Epithelial Tissues..................... I6

Simple Epithelia, I6; Pseudo-stratified Epithelia, 17;

Stratified Epithelia, I 7; Modified Epithelia, I8.

CHAPTER III.

The Sustentative Tissues................... 20

Connective Tissue, 20; Cartilage, 23; Bone, 24; Blood, 26; Bone Marrow, 28.

CHAPTER IV.

The Muscular Tissues

Non-striate (Smooth) Muscle, 29; Striate Muscle, 29.

The Nervous Tissues

CHAP'TER $Y$.

Cells, 3 r; Fibers, 32.

PART III.-MICROSCOPIC ANATOMY OF ORGANS. CHAPTER VI.

Tire Circulatory System

Ca pillaries and Precapillaries, 33 ; Arterioles and Venules, 3.3; Arteries, 34; V'eins, 35; Heart, 35; Lymph Vessels, 35.

CHAPTER VII.

Tile Lymphatic: ORgaNs

Diffuse Lymphoid Tissue, 36 ; Lymph Norlules, 36 ; T'onsil, 37; Lymph (iland or -Node, 37; Hemolymph Giland or -Norle, 38; Siplecen, 3 s. 
The Ductless Glands.

Thymus, 40; Thyreoid, 40; Parathyreoid, 4I; Suprarenal, 4I; Carotid Gland, 42; Hypophysis (Pituitary Body), 42; Epiphysis (Pineal Body), 43 .

\section{CHAPTER IX.}

Serous and Mucous Membranes and Glands.......... Serous Membranes, 44; Mucous Membranes, 44; Glands, 44 .

\section{CHAPTER X.}

The Digestive System.......................

The oral cavity, 46; Lip, 46; Teeth, 46; Tongue, 47; Soft Palate, 48.

The digestive tube, 48; Esophagus, 48; Cardio-esophageal Junction, 49; Stomach, 49; Small Intestine, 50; Large Intestine, $5 \mathrm{I}$; Rectum and Anus, 52 ; Blood Vessels of the Digestive Tube, 52; Nerves of the Digestive Tube, 52 .

The glands of digestion, 52; Salivary Glands, 52; Pancreas, 54 ; Liver, 54 .

CHAPTER XI.

The Respiratory System................... 57

Larynx, 57; Trachea, Bronchi and Bronchioles, . 57; Lung, 57 .

CHAPTER XII.

The Urinary System..................... 59

Kidney, 59; Ureter, 60; Bladder, 6r ; Urethra, 6r.

\section{CHAPTER XIII.}

The Reproductive System.................... 62

Male genital organs, 62; Testis, 62; Ductuli efferentes, 63; Ductus epididymidis, 63; Ductus deferens, 64; Seminal Vesicle, 64; Prostate, 64 ; Penis and Male Urethra, 65. Female genital organs, 66; Ovary, 66; Uterine Tube, 67; Uterus, 68; Decidual Membranes, 69; Vagina, 70; Mammary Gland, 70.

\section{CHAPTER XIV.}

The Skin and Cutaneous Appendages............. 7 I

Skin, 71; Nails, 72; Hair, 73; Sebaceous Glands, 73; Sweat Glands, 74; Mammary Gland, 74. 


\section{A LABORATORY GUIDE IN HISTOLOGY.}

\section{INTRODUCTION.}

The directions in this manual are designed to economize the student's time by reducing to a minimum the misdirected energy which is inevitable when an unfamiliar subject is pursued without guidance. The instructions for each topic are arranged in logical sequence and should be followed in the order given.

Theoretically it is desirable to approach laboratory work with one's mind unbiased by preconceptions derived from texts. Owing, however, to the crowded curriculum this time-consuming method is impracticable. Hence it is essential to prepare for each laboratory period by reading previously an account of the work to be covered that day. In this way a preparation and perspective are gained which can not be obtained by using the laboratory as a reading room.

The ability to make accurate observations is the hardest of all accomplishments, yet it is the one indispensable requisite for scientific achievement. To merely look and to intelligently observe are distinct processes. How often have we looked at our watch only to have to immediately look again when asked the time! Endeavor to develop the ability to make independent observations and conclusions, avoiding, in so far as possible, slavish dependence on books. Follow Agassiz's advice: 'Study Nature not books.' 
Students often waste much time by not planning their work and properly distributing the available working time. Always begin by studying preparations under low magnification, thereby learning the general topography or architecture; finally, under high magnification, systematically work out the detailed structure part by part.

Become thoroughly familiar with a preparation before attempting to draw it. Draw only when its structure has been mastered, a suitable field chosen, and when a decision has been reached as to the features to be portrayed and the size and style of drawing which will best accomplish this end.

Remember that the making of drawings is not Histology. It is, however, a successful method of teaching Histology. The act of carefully drawing an object in its accurate proportions, and of representing faithfully its minute anatomy automatically fixes its structure upon the mind. Moreover, it both stimulates further observation and the correction of erroneous ideas, for it is astounding how imperfect one's knowledge appears when an attempt is made to express it pictorially.

Drawings should portray the actual preparations studied. The adaption of text figures or the including. of features not seen personally constitutes one type of intellectual dishonesty.

Some students seek to excuse poor or slovenly drawings on the basis that they 'are not artists.' Although the natural aptitude for drawing varies, the failure to produce creditable work is inexcusable. Poor drawings are due to insufficient knowledge of the structures involved, and to lack of neatness, care, and endeavor. So-called artistic drawings are often worthless as accurate observational records, whereas patience, interest, and a sharp pencil need never fail to produce an acceptable result. 
Finally, do not fall into the error of basing conclusions on single observations - the particular region you observed may have been atypical or have involved artefacts or pathological changes. Unfortunately Histology, of necessity, deals largely with sections confined to a single plane. Learn to analyze a structure and to reconstruct it mentally as a visualized model. Avoid becoming a two-dimensional histologist: 


\section{PART I.-CYTOLOGY.}

\section{CHAPTER I. \\ THE CELL AND CELL DIVISION.}

\section{A. Resting Cell.}

I. Squamous cells. Place scrapings from the inside of the cheek on a slide, add a drop of alcohol and cover with cover-slip. Note the scale-like cells, their shape, gramules, and prominent nuclei. Are such cells living?

2. Liver cells of salamander. Study single cells intensively, noting: shape and size of cells and nuclei; cell membrane; cytoplasm; spongioplasm (cytoreticulum) of fused cytoplasmic granules; hyaloplasm (cytolymph) occupying interstices; nuclear membrane; chromatin net; chromatin knots (karyosomes); karyoplasm.

3. Mammalian ovum. Study the large spherical ova only, disregarding the surrounding follicle cells and other ovarian tissue. In addition to the structures seen in (2) observe the distinctly rounded nucleolus. Define a nucleolus; a karyosome.

4. Multipolar nerve cell. (From ventral horn of spinal cord.) Identify and study: cytoplasm; 'Nissl granules'; cell processes; nucleus; nucleolus.

Compare corresponding structures in the several types of cells studied. What do you conclude as to the structure of protoplasm? Functions of nucleus and cytoplasm? 


\section{B. Amitosis.}

Study budding cells of yeast or constricting epithelial cells of bladder. Note various stages in the formation of daughter cells.

\section{Mitosis.}

r. Study stages in the mitotic division of animal or plant cells. (Centrosomes and astral rays are not present in the cells of flowering plants.) Become familiar with the characteristic features of the following stages:

(a) Prophase: Loose and close spireme; formation of chromosomes; nuclear membrane?; equatorial plate in side and end view; centrosome?

(b) Metaphase: Nuclear membrane?; chromosome division; spindle; asters.

(c) Anaphase: Stages in the migration of chromosomes to the poles of the spindle.

(d) Telophase: Formation of daughter nuclei; reappearance of nuclear membrane; centrosome?; division of cytoplasm; general return to resting condition.

What does the complicated process of mitosis accomplish? Significance of chromosomes? What are the causative stimuli of cell division?

2. Compare with normal mitoses stages from pathological (cancerous) tissue. Observe mullipolar and asymmetrical tyjes. 


\section{PART II.-HISTOLOGY.}

CHAPTER II.

\section{THE EPITHELIAL TISSUES.}

\section{Squamous.}

\section{A. Simple Epithelia.}

(a) Mesothelium. Study surface of mesothelium, from the mesentery, the cell outlines of which have been made prominent by treatment with silver. Note: shape of cells; sinuous cell boundaries; position and shape of mucleus.

Explain the silver deposit. What is intercellular cement? Define a mesothelium.

(b) Endothelium. Study silvered preparation of capillaries. Compare the shape and outline of cells with those of a mesothelium. Define an endothelium.

(c) Squamous Epithelium (e.g., amnion). In transverse sections, note the spindle shape of cells and position of nuclei. What would be their appearance

\section{Cubical.} in surface view? Could you model a cell with clay?

(a) Transverse sections (e.g., allantois). Note the shape of the cells and the position and size of their nuclei.

(b) Surface view (e.g., allantois). Observe the regularity of the design. How many sides have the

3. Columnar. cells? Reason? Frequency of exceptions?

(a) From the small intestine. Note: shape of cell; 
free end; basal end; cuticula; basement membrane (membrana propria); position of nucleus; arrangement of cytoplasmic granules; unicellular (goblet) gland cells; intercellular cement; terminal bars.

In the goblet cells, note: position of mucleus; cytoplasm; secretion; character of the secretion and stages in its formation; discharged cells.

What is a cuticula? Cuticle? Structure of basement membranes? Origin and function of goblet cells? Does a goblet cell die after it discharges?

(b) Compare the columnar epithelium just studied with that of the colon.

\section{B. Pseudo-stratified Epithelia.}

r. From epididymis. Note: basal cells; fusiform cells; columnar cells; the latter bear false (non-vibratile) cilia which may appear to be fused into 'brushes.'

2. From trachea. The columnar cells bear true cilia.

How does this type of epithelium merit its name? In what situations does it occur? Do the three cell types represent growth stages?

\section{Stratified Epithelia.}

I. Transitional.

(a) From an undistended bladder. Note the number of strata and the basal, club-shaped, and squamous types of cells. How does this tissue merit its name?

(b) From a dislended bludder. Compare with (a). Explain the changed appearance.

2. Stratified squamous.

(a) From the front of the cornea. Note that this epithelium, although but a few cells rlece, shows intergrades between columnar and squamous cells. 
(b) In a typical section, note: basement membrane; the gradual transition in: (I) the shape and size of cells; (2) the condition of the nucleus; (3) the cytoplasmic structure; 'prickle cells' with 'intercellular bridges'; their function?

How is a stratified epithelium originally formed? Does a similar process continue throughout life? Do cilia or unicellular glands ever occur? Explain the causes of cell flattening.

3. Stratified cubical.

e.g., Epidermis of an amphibian. Compare with preceding.

\section{Modified Epithelia.}

I. Glandular.

(a) Unicellular. Goblet cells have been studied in a previous exercise (p. I7).

(b) Multicellular. Study vertical section of the skin of an amphibian. Note: lumen of gland; duct; shape of component cells. From what cells was this gland derived?

(The cytology of gland cells and the structure of various glands will be studied in detail later in the course.)

2. Ciliated.

(a) Stained preparations. Length and size of cilia? How many cilia to a cell? Views as to structure and action?

(b) Intestinal epithelium of the clam. In sections, note: cilia ending in basal bodies (centrosomes?), from which a brush of cytoplasmic fibrilla extends along one side of the nucleus.

(c) Action of cilia. Examine scrapings from a frog's throat placed in normal salt solution. Observe 
ciliary action. How do cilia accomplish effective work? In a small sheet of epithelium in surface view observe the successive wave effects. Compare with waves in water or in a wind-blown field of grain.

3. Pigmented.

(a) Pigmented retinal epithelium. Note: position of nuclei and the pigment-free, adjacent cytoplasm; pigment granules. In lower vertebrates pigment changes its position in darkness and in light. Does this occur in man?

(b) Pigmented epidermal cells. Do all cells of the epithelium contain pigment?

4. Neuro-epithelium.

(a) Gustatory sense cells. Study taste cells from taste bud of tongue. Observe the spindle shape and the sensory bristle at the free end.

(b) Olfactory sense cells. Spindle-shaped cells whose round nuclei occupy a middle zone in the epithelium.

(c) Auditory sense cells. Note the numerous hairs. Their function?

(d) Visual sense cells. Identify the rod and cone cells of the retinal cpithelium and the various differentiated portions of these specialized cells. 


\section{CHAPTER III.}

\section{THE SUSTENTATIVE TISSUES.}

\section{A. Connective Tissue.}

I. Embryonic.

Mesenchyme. Study the mesenchymal cells of a young embryo. Are there discrete cells? What is a syncytium? What occupies the intercellular spaces? What is the significance of studying this embryonic tissue at this point?

\section{Loose fibrous tissue.}

I. Reticular tissue.

(a) Examine under very low magnification a thin slice of a lymphoid organ which has been subjected to tryptic digestion, leaving the connective-tissue framework alone. Observe the minutely branching trestle-work of reticular tissue. Focus freely.

(b) Study the reticulum in sections of a lymphoid organ. Note: cells; their shape; position of mucleus; fibrilla; anastomosing processes; sharpness of cell outlines.

How does reticular tissue differ from mesenchyma? What occupies the interstices between cells? Where in the body is reticular tissue found? What is 'lymphoid tissue'?

2. Mucous tissue.

(a) Study a region in a transverse section of the umbilical cord, remote from blood vessels. Note: cells; muclei; character of cytoplasm; cell processes; in- 
tercellular matrix. Do all processes anastomose? Is this tissue a syncytium? Nature of matrix? Is mucous tissue found in adults?

(b) Study a region near blood vessels. Note: modification of cell shapes; mucin; white fibers and their relation to cells. How are white fibers formed?

3. Areolar tissue.

(a) Tease a small shred of subcutaneous fascia in normal saline. Mount and examine. Note: wavy bundles of white fibers; do either fibers or bundles branch?; single, hair-like, tense elastic fibers; anastomoses?

Compare size of single white and elastic fibers. Adaptation of areolar tissue to its uses?

Draw I per cent. acetic acid under cover slip with filter paper. Observe immediately and explain result.

(b) Sections of the digestive tube show well areolar tissue between the epithelial and muscular layers; with ordinary stains elastic fibers are not seen.

(c) Study preparations of teased fascia stained, e. g., with orange G and orcein. What can be said of the specificity of these stains? Follow single elastic fibers and observe anastomoses.

(d) Study films of areolar tissue stained with methylene blue. Ol)serve various forms of 'conncclive lissuc corpuscles' in the interspaces and, rarely, migratory granular leucocylcs ('mast' cells, etc.).

III. Compact fibrous tissue.

I. Elastic tissue.

(a) Teased or sectioned ligamentum nucha of ox. Note: size, shape, and anastomoses of fibers; fiber sheath?; interfibrillar substance?; what is it?

(b) Study clastic tissue in a section of aorta stained differentially for clastin. Look for branching and 
anastomoses. Where else in the body does dense elastic tissue occur?

(c) Study in surface view an elastic membrane dissected from an aorta. Why called a 'fenestrated membrane'? Revise your knowledge derived in (b).

2. Tendon (compact white fibrous).

(a) Transverse sections. Note: epitendineum (vagina fibrosa); peritendineum (radial septa); blood vessels; perifascicular septa (endotendineum); fasciculi; tendon cells; their-shape, wing-like processes, and nuclei; primary fiber bundles; fibrilla? Real shape of tendon cells? Relation of cells to fiber bundles?

(b) Longitudinal sections. Note: parallel fiber bundles; fibrilla?; nuclei; their arrangement.

Fitness of tendon for its uses? What is the structure of ligaments, fascia, and aponeuroses?

\section{Modified connective tissue.}

I. Adipose tissue.

(a) Study stages in the formation and coalescence of fat droplets (specifically stained) forming in connective tissue. (If such preparations are not available, similar stages in the elaboration of fat droplets may be found in mammary gland cells.)

(b) 'Signet' fat cells. These represent moderately distended cells in connective tissue, free from pressure. Observe the position of the cytoplasm and its abundance near and remote from nucleus. Resemblance of cell to signet ring? Is fat actually present in this preparation? Explain.

(c) Aggregated fat cells (e.g., in the panniculus adiposus). Observe separation into lobules by un- 
modified connective tissue. Shape of cells? Reason? Functions of adipose tissue?

(d) Study in surface view mesentery stained with hematoxylin and Sudan III or Scharlack R. With what structures are fat cells chiefly associated? Significance? Staining activity of hematoxylin? Of Sudan III? Specificity of the fat stain? Its use as a test? Other specific fat stains?

2. Pigment cells.

Observe pigment cells from the dermis of an amphibian or the scale of a fish. Note: nucleus; cell processes; melanin granules in cyloplasm.

Constancy of processes? Correlation of pigment distribution and body color in living animal?

\section{B. Cartilage.}

\section{Hyaline cartilage.}

(a) Mount fresh sections of articular cartilage (e.g., frog's femur) in picric acid solution. Note: perichondrium; cartilage cells (single and in groups) and their arrangement; appearance of cells near and remote from perichondrium; cyloplasmic granules; matrix; blood vessels?

Significance of cartilage cell groups?

(b) Study sections of hyaline cartilage. Note: perichondrium (outer and inner layer) and its composition; transition to carlilage; youngest cartilage cells; single mature cells and cell groups; lacuna; lacunar capsule; matrix; blood vessels?

What are the events of perichondrial cartilage growth? Explain the relation of matrix, lacunar capsule, lacuns, and cells from the standpoint of interstitial cartilage growth. Explain presence of more or less isolated cells and cell groups from the standpoint of growth; can intermediate stages be found? Do lacunx exist in life? What is 'gristle'? Distribution of hyaline cartilage in the body? 


\section{Elastic cartilage.}

In sections (stained for elastin), note: perichondrium; cell groups; capsules; matrix; elastic fibers and their anastomoses; white fibers?; relation to perichondrium; blood vessels?

Color of fresh tissue? Reason? Occurrence of elastic cartilage in the body?

\section{Fibro-cartilage.}

In sections, note: shape, structure, and arrangement of cells; their relation to matrix; arrangement of white fibrous tissue bundles; perichondrium? Distribution of fibro-cartilage?

Compare critically hyaline, fibro-, and elastic cartilage.

\section{Adult bone.}

\section{Bone.}

(a) Decalcified long bone. In a transverse section, note: periosteum; number and composition of its layers; perforating fibers (of Sharpey); their purpose?; periosteal (outer circumferential) lamella; Haversian systems; interstitial lamella; endosteal (inner circumferential) lamelle; endosteum; marrow cavity; with what does it connect?; marrow.

(b) Ground bone.

( $\left.a^{\prime}\right)$ Transverse sections. The organic matter has been removed by maceration. Note: periosteal lamella; Volkmann's canals; Haversian systems; concentric Haversian lamella; lacune; canaliculi; interstitial lamella and arrangement of their lacunæ.

What occupies Haversian canals?; lacunæ?; canaliculi? Inter-relation of these structures? Relation of lacunæ to lamellæ? 
$\left(b^{\prime}\right)$ Longitudinal sections. Observe anastomoses of Haversian canals and systems and their relation to the marrow cavily. Identify all structures possible.

(c) In decalcified preparations of peeled-off lamellæ viewed on the flat (or by means of text figures) observe the fibrous basis of lamelle. What are the decussating fibers (of Sharpey)?

\section{Development of bone.}

(a) Intramembranous ossification.

In sections of developing membrane bone, note: periosteum and its inner layer of osteoblasts; connective-tissue matrix; bone spicules and matrix; osleogenic fibers at the growing tips of spicules continuous with connective-tissue fibers; osteoblasls; bone cells; osteoclasls; Howship's lacunce.

Become familiar with the rôle of each of the above in the process of early and late bone formation.

(b) Intracarlilaginous ossification.

In sections of an ossifying cartilage bone, note: perichondrium and its transition to periosteum; structure of the outer fibrous and inner osteogenic layer of periosteum; periosteal buds of 'irrupted' osteogenic lissue.

Near center of cartilage observe the center of ossification with its primary marrow cavilies. From the extremities toward this center note the change in the shape, size, and arrangement of the cartilage cells. Identify: calcifying carlilage matrix; bony spicules and matrix; osleoblasts; bone cells; osteoclasts; Howship's lacune.

By what means and how completely is calcified cartilage resorbed? Acquire a vivid mental picture 
of the complete process of intracartilaginous ossification in light of the preparation before you. What is the ultimate fate of bone formed in this way? Observe the intramembranous ossification taking place under the periosteum. Its relation to the adult 'long' bone? How do long bones increase in diameter and in length? Origin of Haversian systems? Interpretation of interstitial lamellæ?

\section{Blood.}

I. Erythroplastids and leucocytes.

(a) Make a fresh preparation of amphibian blood. Note: erythrocyles: their size; shape; color; mucleus; leucocytes: their relative abundance; size; shape; pseudopodia; nucleus; cytoplasmic granules; ectoplasm? Select an active leucocyte and observe its changes in form and ameboid movement.

(b) Make a fresh preparation of undiluted human blood and examine immediately. Note: single erythroplastids; rouleaux; leucocytes and their relative abundance; crenated corpuscles. Explain all conditions observed.

(c) Make a fresh preparation of human blood diluted in .85 per cent. saline solution. Note: erythroplastids: their shape (make many observations in surface and edge view); color; nucleus?; changing appearance of red corpuscles at high and low focus; leucocytes: their shape, cell processes?; ameboid movements;? nucleus; cytoplasmic granules.

(d) To the preparation last used add .4 per cent. saline solution by drawing it under the cover glass with filter paper. Shape of erythroplastids? Next draw under tap water. Observe immediately and explain the occurrences of the entire experiment. What is 'laking'? What are 'blood shadows'? 
(e) Nake a new fresh preparation of human blood and dilute with .I I per cent. saline solution. Observe the effect on red corpuscles and formulate a rational explanation for all the phenomena observed in (d) and (e).

\section{Blood platelets.}

Prick finger through a drop of methyl violet in .85 per cent. saline solution. Mount and examine. Note: leucocytes and their nuclei; blood platelets: their shape, relative size, frequency, and structure; tendency to aggregate in groups? What are platelets? Origin? Function?

\section{Stained smears.}

In stained preparations determine the approximate relative frequency of red and white corpuscles. Study carefully the cytology of leucocytes according to the following classification:

(I) Lymphocytes. (about the size of red corpuscle or somewhat larger): narrow rim of non-granular cytoplasm; round checkered nuclei.

(2) Large mononuclear leucocytes (two or three times size of red corpuscles): considerable non-granular cytoplasm; pale, round or bean-shaped nuclei.

(3) Polymorphonuclear leucocytes (larger than red corpuscles): granular cytoplasm; nucleus variously constricted.

(a) Eosinophiles (oxyphiles): coarse eosinophilic granules.

(b) Basophiles (mast cells): coarse basophilic granules.

(c) Neutrophiles: fine neutrophilic granules.

Compare critically each type with the others and estimate the relative frequencies. Do true polynuclear forms occur? Are blood platelets present? Which types are most actively ameboid and phagocytic? 
4. Fibrin.

Primary origin of basophilic and eosinophilic granules?

Study stained fibrin. Note: fibrin filaments and their arrangement; blood platelets; relation of platelets to fibrin; significance?

\section{Blood crystals.}

Examine crystals of (a) hemoglobin and (b) hemin and observe their size, shape, color, and relation to one another. Compare.

6. Technique of smears and staining.

(a) Wright's Blood Stain.

(I) Touch drop of fresh blood to slide or cover glass (cleaned with alcohol). With a quick, even stroke of a cover glass spread this drop into a thin film. Wave smear preparation in air to hasten drying.

(2) Cover preparation with Wright's stain and allow it to act for one minute.

(3) Add to the stain on the film about an equal amount of distilled water, drop by drop, until the stain becomes translucent (not transparent) and a yellowish, metallic scum appears on the surface. Let stand for two and one-half minutes (not longer).

(4) Decolorize by dipping preparation into distilled water until the thinnest parts of the film are pinkish orange when held to the light. The original blue coloration should practically disappear.

(5) Draw off surplus water, blot gently, and set away to dry.

(6) When thoroughly dry, mount in balsam.

(b) Jenner's Blood Stain.

(I) Stain smears for two to five minutes.

(2) Rinse briefly in water, blot, dry, and mount.

\section{E. Bone Marrow.}

I. Red bone marrow. In sections and smears, note: megakaryocytes; myelocytes; stages (erythroblast; normoblast) in the formation of erythroplastids; various types of leucocytes; reticulum; fat.

Shape of megakaryocyte nucleus (decide only after studying many)? Function of megakaryocytes? Name all functions of embryonic and adult bone marrow. In what situations does it occur?

2. Yellow bone marrow. Compare with red marrow as to structure, function, and distribution. 
CHAPTER IV.

THE MUSCULAR TISSUES.

A. Non-striate (Smooth) Muscle.

I. Teased cells. Note: shape of isolated cells; shape, position, and size of nucleus; sarcoplasm, perinuclear cytoplasm; myofibrils?

2. Sections (e. g., bladder; intestine).

(a) Observe the inter-relation of cells cut longitudinally. Compare apparent lengths of cells with isolated elements. Explain. Compare shape of nuclei with those of connective tissue; diagnostic value?

(b) In fibers cut transversely, note: shape and variable size of fibers; position of mucleus; intercellular malerial; arrangement in bundles. Explain variable size of fibers and inconstancy of nucleus. Distribution of smooth muscle in the body?

3. Blood supply. In sections of injected smooth muscle observe capillaries and their anastomoses and relation to muscle fibers.

\section{B. Striate Muscle.}

\section{Cardiac muscle.}

I. Longitudinal sections. Note: shape, size, and branching of 'cells'; sarcolemma; intercalated discs; shape and position of nuclei; sarcoplasm; myofibrils; light (isolropic) and dark (anisotropic) bands; intermuscular connective tissue.

Do intercalated discs mark cell boundaries? Is there always a nucleus between two successive discs? Search preparation for evidence on these points.

2. Transverse sections. Note: fibers; their variable shape; position of nuclei; sarcoplasm; position of 
myofibrils; sarcolemma; intermuscular connective tissue; capillaries. Explain frequent absence of nuclei.

\section{Skeletal muscle.}

I. Teased fibers. Tease a small fragment of fresh muscle in normal saline solution and examine. Note: size and shape of fibers; myofibrils; cross striations; muclei; sarcolemma.

Add I per cent. acetic acid and observe again.

2. Longitudinal sections. Note: size and shape of fibers; branching?; endomysium and its muclei; sarcolemma; shape, position, and number of muscle cell nuclei; sarcoplasm; myofibrils; sarcostyles (Koelliker's columns); light (isotropic) bands, bisected by Krause's membrane $(Z)$; dark (anisotropic) bands bisected by Hensen's membrane $(M)$; on either side of Krause's membrane an accessory membrane $(N)$.

The $\mathrm{Z}$ lines divide the fibers into homologous segments (sarcomeres). Number of nuclei to a fiber? Is the fiber a syncytium? Length of a fiber? Study the sarcolemma in torn or shrunken fibers.

3. Transverse sections. Note: epimysium; perimysium; fascicles; endomysium; blood vessels; sarcolemma; sarcoplasm; muclei; their position; areas of Cohnheim; fibrils.

Relation of Cohnheim's areas to Koelliker's columns? Interpretation of Cohnheim's areas? What visible changes occur in muscle fibers during contraction? Theories of contraction? Why do muscles enlarge with exercise? Compare critically cardiac and skeletal muscle.

4. Blood supply. In sections of injected skeletal muscle observe the abundance of anastomosing capillaries and their intimate relation to muscle fibers.

5. Relation of muscle to tendon. Study longitudinal sections through the junction of the two. Observe the mode of insertion and attachment of muscle fibers. Do muscle fibers end abruptly? 
CHAPTER $V$.

THE NERVOUS TISSUES.

A. Cells.

I. Multipolar cell (of spinal cord). Note: mucleus; nucleolus; chromatin?; cytoplasm; neurofibrils; Nissl granules?; dendrons and their number; axon; how distinguished from dendron?; implantation cone (axon hillock).

Toluidin blue preparations. Compare structures with those just seen. Note: size, number, and location of ' $N$ issl granules.' Are they found in dendrons? In axons? Function? Causes and significance of chromatolysis?

2. Purkinje cell (of cerebellum). Note: shape of cells; axon; collaterals?; dendrons and extent and system of branching.

3. Pyramidal cell (of motor cortex). Note: shape; direction of apex; axon collaterals?; dendrons; branches.

4. Spinal ganglion cell. Note: cell structure; intracellular neurofibrils?; short intra- or extracapsular dendrons? 'end discs'?; fused axon and dendron; its intracapsu- ' lar convolutions; do its components again separate?; capsule and its relation to the surrounding connective tissue.

5. Sympathetic ganglion cell. Compare with (4) structure for structure. Wherein do they differ?

Size limits of nerve cells? What is a neuron? Its maximum length? Define an axon and dendron. Function of each.

6. Neuroglia cells and fibers. Identify 'spider' and 'mossy' cells. Appearance and distribution of fibers? Their relation to the cells? Origin and function of neuroglia tissue? 


\section{B. Fibers.}

\section{Myelinated fibers.}

I. Teased fibers. Note: axis cylinder; neurofibrils?; myelin sheath; myelin segments; incisures and segments of Schmidt-Lantermann; their interpretation?; neurilemma (sheath of Schwann); its nuclei; nodes of Ranvier; internodal segments.

Why does osmic acid stain myelin black? Is the myelin sheath cellular? Its probable function? What is a possible explanation for the existence of nodes of Ranvier? Length of neurilemma cells?

2. Transverse section of a peripheral nerve trunk. Note: epineurium; perineurium; endoneurium; Henle's sheath; fascicles; fibers; axis cylinder; neurofibrils; neuroplasm; myelin sheath; neurilemma.

Are fibers uniform in size? Significance? Are the neurilemma and sarcolemma homologous structures?

3. Study preparations which show the neurokeratin framezork selectively stained. In silvered preparations observe the 'cross of Ranvier' at the nodes. Explain.

\section{Unmyelinated fibers.}

Observe: axis cylinder; neurilemma?; sheath muclei. Do nodes occur?

III. Nerve terminations.

Study preparations showing: free nerve endings; muscle spindles; tactile and lamellar corpuscles, motor end plates, etc. 


\section{PART III.-MICROSCOPIC ANATOMY OF ORGANS.}

\section{CHAPTER VI.}

\section{THE CIRCULATORY SYSTEM.}

\section{A. Capillaries and Precapillaries.}

I. Study capillaries in pia mater or mesentery. Note: endothelium; endothelial muclei; cell boundaries; supporting sheath? How can the diameter of these vessels in micra be estimated?

2. In the same preparation find precapillaries. Presence of other coats besides endothelium? How can arterial precapillaries be distinguished from venous precapillaries? Distinguish the nuclei of endothelium, smooth muscle, and connective tissue by their shape and orientation.

3. Observe the shape and orientation of endothelial cells in silvered mesentery or pia mater. Nuclei?

4. Study (e.g., in placental villi) transverse sections of capillaries and precapillaries.

\section{B. Arterioles and Venules.}

I. Examine larger vessels in the pia mater or mesentery. Distinguish an ouler (conneclive lissuc) coal, middle (muscular) coal, and inner (cndothclial) coat. Differentiate the nuclei of these coats.

2. In sections find an arleriole and venule of the same size. 
Note: tunica intima; tunica media; tunica externa. Compare their relative thicknesses. Relative size of lumina?

(a) Arteriole. In the tunica intima peripheral to the endothelium distinguish the internal elastic membrane. Is it a complete membrane? What fundamental tissues comprise the media and externa?

(b) Venule. Compare the intima carefully with that of the arteriole. Internal elastic membrane?

\section{Arteries.}

I. Transverse section of a medium-sized artery. Observe the relative thickness of the three tunics and the fundamental tissues in each.

(a) Tunica intima. Note: endothelium; how many cells thick?; subendothelial layer; what fundamental tissue is it?; internal elastic membrane; to which tunic does it belong?

(b) Tunica media. Note: arrangement and relative amount of elastic and muscular tissue; reason?; presence of elastic membranes?; reason?

(c) Tunica externa. Is it sharply delimited? Tissues present and their arrangement? Note: external elastic membrane; is it a single membrane?; to what tunic does it belong?; vasa vasorum.

2. Transverse section of the aorta. Compare intensively with medium-sized artery. Note: difference in tunica intima; composition of media; amount and disposition of elastic tissue; relative thickness of tunics.

3. Examine a fenestrated membrane mounted on the flat. Propriety of this name?

4. For comparison study a small arlery. Observe the relative thickness of the tunics and compare the amount 
and distribution of elastic tissue in small-, medium-, and large-sized arteries.

\section{Veins.}

I. Transverse section of a medium-sized vein. Observe the relative thickness of the three tunics. Follow the directions above for a medium-sized artery. Do the following structures occur: internal elastic membrane?; elastic tissue in media?; external elastic membrane? Compare with medium-sized artery part for part.

2. Study for comparison a small vein. Is there a subendothelial layer? Note relative thickness of tunics and compare with a medium-sized vein and a small artery.

3. Longitudinal section through a vein and valve. Note: lunics of vein; arrangement of smooth muscle in media; tunics involved in the valve; constituent tissues of valve.

\section{E. Heart.}

In a section identify the three layers corresponding to the tunics of a blood vessel. In the epicardium observe an outer mesothelium and inner areolar tissue. Between the cardiac muscle fibers of the myocardium note the endomysium. The endocardium consists of endothelial and subendothelial layers.

\section{F. Lymph Vessels.}

Transverse section of the thoracic duct. Identify the three tunics. Which type of blood vessel does it most closely resemble? Compare with a blood vessel of the same caliber. 
CHAPTER VII.

THE LYMPHATIC ORGANS.

A. Diffuse Lymphoid Tissue.

I. Study the structure of lymphoid tissue (formerly called adenoid tissue). What fundamental tissue forms the branched and anastomosing meshwork? Identify the various types of cells occupying the interstices.

2. Observe the diffuse lymphoid tissue beneath the epithelial lining of the intestinal tract.

\section{B. Lymph Nodules.}

I. Solitary nodules.

These may be found just beneath the intestinal epithelium. Note: their greater compactness, which delimits them from the surrounding diffuse lymphoid tissue; pale germinal center; does every nodule possess one?; mitoses.

Compare the cells in the germinal center and periphery with respect to the amount of cytoplasm and the size and stainability of their nuclei. Why is the germinal center pale? Appropriateness of this name?

Compare with the more frequent solitary nodules of the appendix.

2. Aggregate nodules (Peyer's patches).

Examine a section of the small intestine passing through a Peyer's patch. Are the constituent nodules confluent or separated by fibrous tissue?

Compare with the nodules of the appendix. 


\section{Tonsil.}

I. Palatine tonsil.

Study vertical sections. Note: epithelium; how many cells thick?; branching crypts; diffuse lymphoid tissue; lymph nodules; germinal centers; capillaries; trabecula; connective-tissue capsule; mucous glands.

Does the tonsillar tissue invade the submucosa? Infiltration of epithelium by leucocytes? Where most frequent? What are 'salivary corpuscles'? Why is the tonsil a frequent portal of infection?

\section{Lingual tonsil.}

Compare its structure with the palatine tonsil. Observe the central pit, or crypt, of each lymphoid mound. These mounds in the aggregate constitute the 'lingual tonsil.'

3. Pharyngeal tonsil.

Note: lymph nodules; epithelium; pits; the lobulation and poorly circumscribed limits of the mass.

What are the 'adenoids' of clinicians? What are 'tubal tonsils'?

\section{Lymph Gland or Node.}

I. General architecture. (From sections of an entire gland.) Note: hilus; capsule and septa-like trabecula extending inward from it; cortex and lymph nodules; medulla and medullary cords; peripheral lymph sinus; cortical and medullary lymph simuses; blood vessels.

2. Detailed structure.

(a) Capsule and corlex. Note: capsule and trabecula; their constituent tissues; relation of reticulum to trabecula; lymph nodules; their number and relation to trabeculæ; germinal centers and types of cells present; relation of nodule to sinuses; peripheral simus; endothelial lining?; connection 
of peripheral with central sinuses; relation of central sinuses to trabeculæ.

(b) Medulla. Note: medullary cords; germinal centers?; sinuses and contents; endothelial lining?; blood vessels; their relation to trabeculce.

(c) Look for evidence of phagocytosis by leucocytes and by reticulum cells. What are the functions of lymph glands? Are lymph sinuses well-defined endothelial tubes or merely irregular, washed-out channels in the lymphoid tissue? Have they an endothelial lining, and if so is it complete?

Be able to trace the complete course of the lymph and blood into and out of the gland. Do the blood capillaries and lymph sinuses communicate?

\section{E. Hemolymph Gland or Node.}

Compare part for part with the lymph gland, using the outline above. Are there distinct lymph nodules or germinal centers? A distinct cortex and medulla? Observe carefully the sinuses and their contents. Are there said to be lymphatic connections? Functions of hemolymph gland? Where found? Normal color?

\section{F. Spleen.}

I. General architecture. Study vertical sections in a region near the capsule. Note: capsule; at right angles to it interlobular trabecula which bound lobules; intralobular trabecula; splenic nodules (Malpighian corpuscles); germinal centers?; splenic pulp; arteries; veins.

About how wide is a splenic lobule? Into how many compartments is it said to be divided? Significance? 
2. Detailed structure.

(a) Connective-tissue framework. In the capsule distinguish the outer tunica serosa; what is its structure?; a more common name for it? Identify the inner tunica albuginea; what fundamental tissue present?; how does it merit its name? Composition of trabeculce? relation of trabeculæ to the reticulum?; presence of veins in trabeculæ.

(b) Splenic nodule. Note: kinds of cells present; mitoses; 'central' artery; its usual position? Why are two central arteries frequently observed? Occurrence of germinal centers? Determine if possible the density of the reticulum at the center and periphery of nodules.

(c) Splenic pulp. Note: pulp cords; intercordal splenic sinuses showing fenestrations in transverse section; erythroplastids; nucleated erythroblasts?; lymphocytes; other leucocytes.

Identify the splenic cells with large rounded nuclei and considerable cytoplasm; evidence of phagocytic action?; what type of leucocyte do they resemble?; are the two identical? Smear preparations of the pulp tissue are instructive.

What are the functions of the spleen as indicated by your observations? Compare with hemolymph gland as to structure and function. Contrast the spleen with a lymph gland.

3. Blood supply. If sections of injected spleen are available, study the relation of the arteries and veins to each other and to the septa and splenic nodules. In any case understand thoroughly the complete circulation of the blood. 


\section{CHAPTER VIII.}

\section{THE DUCTLESS GLANDS.}

\section{A. Thymus.}

I. General architecture. In sections, identify: lobes; lobules, each invested with a fibrous capsule which serves also as an interlobular septum; intralobular septa; cortex; medulla; thymic (Hassal's) corpuscles; blood vessels.

Are cortex and medulla sharply demarked? Occurrence of germinal centers? Extent inward of intralobular septa? May the medulla interconnect lobules?

2. Detailed structure. Identify the types of cells found in the close-meshed reticulum. Mitoses? What differentiates the lymphoid tissue into a distinct cortex and medulla?

Study a thymic corpuscle. Where found? Note: central cells; number?; their appearance and contents; peripheral cells; their arrangement; stainability of the corpuscle; views as to its origin?

Origin of the lymphocytes? How much of the thymus is of entodermal origin?

What functions may be inferred? Action of its internal secretion? Correlation between size of thymus and age of the individual?

Contrast critically the thymus, spleen, and lymph gland.

\section{B. Thyreoid.}

I. General architecture. In sections, identify: fibroelastic capsule; interlobular septa; lobules; follicles; colloid; interfollicular stroma and blood vessels. 
2. Detailed structure.

(a) Follicular epithelium. Note: number of cells thick; correlation of follicle size, cell shape, and amount of colloid content; position of mucleus; character and stainability of cytoplasm; basement membrane?

Examine the character of the colloid. Cells, vacuoles, or other inclusions? Why usually a spiny border? Relation of colloid to the internal secretion?

(b) Interfollicular stroma. Constituent tissues? Observe the rich vascular supply and its intimate relation to the follicles; significance?

Trace the probable path of exit of the internal secretion. Functions of the thyreoid?

\section{Parathyreoid.}

Study sections. Identify: thin capsule; lobules?; cellular cords or masses; connective-tissue stroma; blood vessels.

Examine the cellular cords or masses and observe the poorly staining chief cells and acidophile cells. Note the relation of the abundant sinusoidal capillaries to the gland tissue. Is colloid ever found?

Origin, location, and function of the parathyreoids?

\section{Suprarenal.}

I. General architecture. Study vertical sections. Identify: capsule; in cortex, zona glomerulosa, zona fasciculata, and zona relicularis; compare their breadths; medulla; blood vessels.

2. Detailed structure.

(a) Cortex. Note: fibro-elastic capsule; delicate trabecula extending inward and bearing capillaries; shape and 
arrangement of cells in each zone; intimate relation to capillaries; fat-vacuolated cells of $z$. fasciculata; pigmentcontaining cells of $z$. reticularis.

(b) Medulla. Note: cellular cords and masses; usual stellate appearance of chromaffin cells; reason?; their intimate relation to sinusoids; veins; arteries; nerve trunks and cells?

Correlate the adult structure of the suprarenal with its development. What is adrenalin? Where formed and its function? What is the chromaffin reaction?

3. Blood supply. By means of injected sections, or texts, learn the course of the blood.

\section{E. Carotid Gland.}

In sections observe the spheroidal cell masses embedded in connective tissue and the constituent cords of chromaffin cells bordered by sinusoidal capillaries. What is its origin, location, and probable function? Compare with descriptions of the coccygeal gland. Is the latter a chromaffin organ?

\section{F. Hypophysis (Pituitary Body).}

I. General topography. (Sagittal sections.) Identify: capsule; anterior (glandular) lobe; interglandular cleft; intermediate portion with colloid-filled cysts; posterior (neural) lobe.

\section{Detailed structure.}

(a) Anterior lobe. Note: fibrous capsule; delicate trabeculce extending inward from it; epithelial cords; branching and anastomoses?; shapes of cells and their varieties as to the character and stainability of their cytoplasm; arrangement of these types of cells in the cords; relation of cords to sinusoidal capillaries. Compare the anterior lobe with the parathyreoid. 
(b) Intermediate portion. Observe: interglandular cleft and its lining; epithelium-lined cysts containing 'colloid'; character of each; relative abundance of capillaries as compared to anterior lobe.

(c) Posterior lobe. Study the delicate capsule and the neuroglia cells and fibers.

How does the hypophysis develop and what functions are ascribed to the anterior and intermediate lobes?

\section{G. Epiphysis (Pineal Body).}

In a section, observe: capsule; Irabecula; poorly defined lobes; pigmentcontaining cells; acervulus cerebri (brain sand); rich blood supply.

What is the 'pineal eye' of certain lizards. Has the epiphysis any known function in man?

Name all other organs with internal secretion not yet studied. 
CHAPTER IX.

\section{SEROUS AND MUCOUS MEMBRANES AND GLANDS.}

\section{A. Serous Membranes.}

Study sections of serous membranes. Kind of epithelium? What special term is applied to it? Nature of tunica propria? What is the subserous layer? In what situations is it absent? What are 'stomata' and how are they interpreted? Character of the secretion and its use?

How do serous membranes compare with synovial membranes and burse in structure?

\section{B. Mucous Membranes.}

Study sections of mucous membranes from various locations. Compare in each the type of epithelium, membrana propria* (basement membrane), and tunica propria. Occurrence of a muscularis mucosa? In what locations is the tunica propria infiltrated with lymphocytes? What other structures course in the tunica propria? Compare the tunica propria and submucosa as to structure, compactness, and function. Presence of glands in submucosa? Where do mucous membranes occur? Functions?

\section{Glands.}

I. Physiologic types. Mucous and serous glands. Study sections in detail. Compare: cytoplasm and secretion; * Prominent in trachea. 
their character and stainability; position and shape of nucleus. In a mixed gland (e. g., submaxillary) these contrasts are sharp.

Difference in the fresh secretions of the two types of gland? Learn the secretory cycle in each type and find illustrative stages. What is a 'crescent' or 'demilune'? How is its secretion carried away?

The ductless glands have been studied (pp. 40-43). Specialized types, such as cytogenic glands (p. 62) and sweat and sebaceous glands (pp. 73-74) will be taken up later in the course.

2. Histologic types. Observe the following types: (I) simple tubular (e.g., intestinal glands or crypts); (2) convoluted tubular (e.g., sweat glands); (3) branched tubular (e. g., gastric glands); (4) simple and branched saccular (sebaceous glands).

Occasionally instructive sections of compound glands are found: (I) compound tubular (e.g., kidney; testis); (2) compound tubulo-alveolar (e. g., salivary glands; pancreas); compound saccular (mammary gland). 


\section{CHAPTER X. \\ THE DIGESTIVE SYSTEM.}

I. The Oral Cavity.

\section{A. Lip.}

In a vertical section, note: differences in thickness, compactness, and structure of epidermis and oral epithelium; variations in height of connective-tissue papilla; why is the lip red?; transitions at edge of lip; presence of hairs, sebaceous glands, and sweat glands in skin, and of labial glands (what type?) in submucosa.

Compare the looseness of the mucous membranes of the lip, tongue, and hard palate, and the skin of the back of the hand.

\section{B. Teeth.}

I. General topography. Examine a longitudinal section of an entire tooth. Identify: crown; neck; root; pulp cavity; root canal; enamel; cement; dentine.

2. Detailed structure.

(a) Decalcified tooth. Study the contents of the pulp cavity in sections. Note: reticular tissue; blood vessels; nerves?; odontoblasts and their dentinal (Tomes') fibers extending into the dentinal canals.

Function of the odontoblasts? . How many dentinal fibers to an odontoblast? Their function? Why is dentine sensitive to pain?

If the section is of a developing tooth, identify the inner 
cnamel epithelium and its component ameloblast cells. Observe the cuticular Tomes' processes extending from the individual odontoblasts. How is enamel formed?

(b) Ground sections.

(a') Enamel. Note: enamel prisms; their shape, arrangement, and markings; contour lines (of Retzius); enamel-dentine junction; interglobular spaces.

$\left(b^{\prime}\right)$ Dentine. Observe the dentinal tubules. What is their shape, arrangement, and relation to the pulp cavily? Study their branching and anastomoses. Identify the contour lines (of Owen) and the granular layer (of Tomes).

(c') Cement. Observe the lacuna and canalicula. Are lamella well marked? What is cement and how is it formed?

\section{Tongue.}

I. General architecture. Study vertical sections. Note: mucous membrane and lingual papilla; dense submucosa and regional variations in the firmness with which the mucosa is bound to it; lingual glands; lingual tonsil?; longitudinal, transverse, and vertical muscle bundles; lingual septum.

What is the method of insertion of muscle fibers into the connective tissue of the mucous membrane?

2. Lingual papillæ.

(a) Filiform (and conical) and fungiform papilla. Note: their relative abundance; shape; fitness of their names?; primary and secondary connective-tissue elevations, or papille, extending into them; presence of laste buds?

Compare the cornification of epithelium in the two.

(b) Vallate papille. Propriety of name? Note: restricted location of taste buds and secondary papille; von 
Ebner's glands; what type of gland? Where do the ducts open?

(c) Foliate papilla. Compare with vallate. How do they differ in gross appearance? Relative development in rabbit and man?

(d) Taste bud. If possible distinguish: darker and more slender taste cells ending in cuticular bristles which extend into the taste pore; paler and more robust supporting cells.

\section{Soft Palate.}

Study vertical sections. Note: variation in epithelium on nasal and oral surfaces; taste buds?; palatine glands; fat; muscle.

The palatine, lingual, and pharyngeal tonsils have been treated under lymphoid organs (p. 37).

\section{The Digestive Tube.}

In studying the digestive tube it is important to recognize the unity of architecture throughout. Each division from within outward possesses the following coats: (I) mucosa, including the muscularis mucosa; (2) submucosa; (3) muscularis, with its inner circular and outer longitudinal layers; (4) serosa or adventitia.

Compare carefully the structure and relative extent of development of these parts in the various divisions of the digestive tube.

\section{A. Esophagus.}

Study sections preferably at various levels. Note: mucous membrane; character of epithelium; connective-tissue papilla; lymph nodules?; direction of fibers in muscularis mucose. In the submucosa observe the 'deep' esophageal glands and 
their long ducts; type of gland cell? Study the structure and arrangement of the muscular coats and of the fibrous adientitia.

Significance of extensively folded mucosa? How are the various coats affected by the passage of food? What is the distribution of striated muscle? Is the adventitial coat a serosa?

\section{B. Cardio-Esophageal Junction.}

Study longitudinal sections, observing the abrupt transition between the two types of epithelium.

Compare the 'superficial' esophageal glands with the 'deep' ones already studied as regards depth of position and stainability. Are superficial glands located elsewhere in the esophagus?

Observe the type of epithelium lining the cardia and compare the cardiac glands with the superficial esophageal glands. Mucous cclls? Acidophilic colls? Interpretation of cardiac glands? Extent of area occupied?

\section{Stomach.}

I. Compare vertical sections through various regions. Note: folded mucosa; absence of papilla; gastric pits; glands; lymph nodules?; muscularis mucosa; how many layers?; submucosa; muscularis; presence of an innermost oblique muscular layer?; scrosa; how is it different from the adventitia of the esophagus?

2. Cardia. This has been studied in conjunction with the esophagus.

3. Fundus or corpus.

(a) Mucosa. Study vertical sections in detail. Determine the shape, length, and extent of branching of the 
gastric (fundus) glands and their relation to the gastric pits (foveoli). Tunica propria? Compare the surface epithelium with that of the pits. Why do not goblet cells occur?

(b) Gastric glands. Identify in each a neck, body, and fundus. Is there a distinct lumen? Observe the shape, position, and relative abundance of chief cells. Location of the mucleus and the character and stainability of the cytoplasm? Make similar observations on the parietal cells; where are they most numerous?; how does their secretion reach the lumen? What functions are attributed to each type of cell?

4. Pylorus. Compare the pyloric and fundic epithelium as regards: depth of pit; length and tortuousness of gland; shape of gland cells and character of their cytoplasm. Nature of the secretion?

\section{Small Intestine.}

\section{Duodenum.}

(a) Identify in sections the various coats and compare with esophagus and stomach. Note: plice circulares; papille; intestinal (Lieberkiihn's) glands; duodenal (Brunner's) glands.

(b) Mucosa. Study the columnar epithelium, noting goblet cells and the striate cuticula. In the tunica propria observe the diffuse lymphoid infiltration and occasional lymph nodules. How do the latter affect the villi and glands over them? What coats are responsible for (I) plica circulares; (2) villi?

(c) Villi. In villi cut variously observe the core of lymphoid tissue and identify the axially placed lacteal and the delicate blood vessels. Smooth muscle fibers? What is the shape of an entire villus? 
(d) Intestinal glands. Depth of penetration into mucosa? Branching? If possible identify the granule cells of Paneth. Their significance? Are these glands actual out-pocketings of the surface epithelium or merely crypts formed by contiguous villi? How may glands and villi be distinguished in transverse section?

(e) Duodenal glands. Where located? Appearance and stainability of the cells and nature of secretion? Where do the ducts open?

\section{Jejunum and ileum.}

Follow the directions for the duodenum. Does the duodenal (Brunner) type of gland occur? Relative prominence of plica circulares? 'True shape of entire jejunal and ileal villi? Look for aggregate lymph nodules (Peyer's patches) and compare with solitary nodules. Location of aggregate nodules?

I. Colon.

\section{E. Large Intestine.}

Study sections. Note: absence of plica circulares and villi; columnar, lining epithelium; does it contain goblet cells?; elongated intestinal glands with abundant goblct cells; frequent solitary lymph nodules; are these confined to the mucosa?; arrangement of longitudinal muscle coat into tania; thickness of longitudinal coat between tanix? Relative length of intestinal glands in large and small intestine?

\section{Appendix or vermiform process.}

Compare with colon. Tania? Observe the extreme infiltration of the mucosa by lymphocytes and the number and position of the more or less confluent lymph nodules. Is the muscularis mucose intact? 


\section{F. Rectum and Anus.}

In a longitudinal section observe the step-like transition in epithelia. Size of rectal glands? Other differences from colon? Composition of internal and external sphincter? Type of circumanal glands?

\section{G. Blood Vessels of the Digestive Tube.}

Examine sections of injected stomach or intestine. Distinguish the intramuscular- and extensive submucous plexuses, whence axial arteries extend into the villi and peripherally placed veins descend the villi to retrace the arterial course. Richness of blood supply in the several coats?

What is the arrangement of the lymphatics?

\section{H. Nerves of the Digestive Tube.}

Examine for nerve cells the various sections already studied. Look for the myenteric plexus between the muscle coats; for the submucous plexus in the submucosa. If heavy-metal preparations are available, cells and fibers are easily demonstrated.

Central origin of these fibers? Probable peripheral distribution? Functions?

\section{The Glands of Digestion.}

\section{A. Salivary Glands.}

The small glands (labial, lingual, palatine, and von Ebner's) have been studied in connection with the oral cavity. (pp. 46-48).

\section{Parotid.}

(a) General architecture. In sections, identify: capsule; septa; lobules; interlobular ducts; intralobular ducts; alveoli or acini; blood vessels. 
(b) Detailed structure.

(a') Alveoli. Note: shape; size of lumen; gland cells; character and stainability of their cytoplasm; zymogen granules?; position of muclcus; basement membrane.

The parotid is a compound tubulo-alveolar gland; explain. Is the parotid a serous, mucous, or mixed gland?

(b') Duct syslem. Continuous with the alveolus is the intercalary (intermediate) duct, of flattened cells; next in order is the secretory (salivary) portion, of simple columnar cells with basal striations; finally comes the excretory portion with cells pseudostratified or in two layers.

Distinguish these divisions in transverse and longitudinal section. Determine which are interlobular, intralobular, or both.

\section{Submaxillary.}

Is the general architecture and duct system like that of the parotid? Estimating from their relative frequencies in sections, how do the intercalary and secretory ducts compare in length with those of the parotid?

Identify mucous, serous, and mixed alveoli and compare as to shape, size of lumen, character and stainability of cyloplasm, and position of nucleus. What is the proportion of mucous to serous alveoli? What are 'crescents' or ' $d \mathrm{cmi}$ lunes'? Their abundance and significance? How is their secretion drained?

\section{Sublingual.}

Compare with the submaxillary. Is there a distinct capsule? Judging from their frequency in sections, are the secrelory ducts long or short? Do intercalary ducls occur? Are there any purely serous alveoli? Can this be decided 
from single sections? Compare with submaxillary for frequency of crescents and the total ratio of serous to mucous cells.

\section{B. Pancreas.}

I. General architecture. In sections, identify: lobules; capsule; inter-and intralobular septa and ducts; alveoli or acini; pancreatic islands (of Langerhans); blood vessels.

2. Detailed structure.

(a) Alveoli. Note: shape (compare with parotid); lumen?; basement membrane; gland cells; - position of nucleus; zymogen granules and their position; centro-alveolar or centro-acinal cells; what are they? Nature and function of glandular secretion?

(b) Duct system. Elongated intercalary (intermediate) ducts, continuous with centro-alveolar cells, pass over into interlobular (excretory) ducts. Distinguish these divisions. Do secretory ducts occur?

(c) Pancreatic islands. Observe their size, shape, frequency, position, and relation to neighboring alveoli. Shape, character, and stainability of the cells? Note their arrangement into anastomosing cords and the intimate relation to capillary sinusoids. Ducts? Do connections exist between islands and alveoli or their ducts? Functions of the islands?

What gland does the pancreas most resemble in structure and function? Compare, enumerating five important structural differences.

\section{Liver.}

I. General architecture. Study sections of pig and human liver. Identify: capsule (of Glisson); lobules; their size, shape, and arrangement; interlobular septa; at the 
angles of the lobules, portal canals containing each a branch of the portal vein, hepatic artery, and bile duct; central vein of lobule, from which radiate simusoids separated by cords or trabeculce of liver cells; sublobular veins coursing independently in the interlobular connective tissue.

In what essential respect does the liver of the pig differ from that of man?

\section{Detailed structure.}

(a) Connective-tissue framework. Fundamental tissues present in the serous capsule? In the interlobular septa? Can an intralobular reticulum be identified? What are stellate cells (of Kupfer)?

(b) Portal canal. Look for these at the angles of lobules. Identify: thin-walled interlobular veins (branch of portal), the largest of the three chief components; interlobular artery (branch of hepatic), the smallest of the three; bile duct, intermediate in size. Search also for lymphatic vessels and nerves.

(c) Parenchyma. In the lobules observe the radial cords of hepatic cells. Arrangement and anastomoses? How many cells thick are the cords? Character of cytoplasm? Presence in cytoplasm of fat globules or pigment? May cells have more than one nucleus? Mark the intimate relation to bordering simusoids.

(d) Duct system. If heavy-metal preparations are available, ${ }^{*}$ study the arrangement of intralobular bile capillaries. With how many cells is each in contact? Structure? In sections of portal canals examine the epithelium and fibroelastic coat of the interlobular bile ducts. Method of union between interlobular bile ducts and bile capillaries?

3. Blood supply. Study sections, preferably injected.

* Jile capillaries are alse, [rominent in ordinary sections of salamander liver. 
Blood enters the liver through the interlobular branches of the hepatic artery and portal vein, already seen within portal canals. Quantity, quality, and destination of blood in each? Within lobules note the extent of radial capillary sinusoids, their anastomoses, and convergence to the intralobular (central) vein. Look for lobules cut to show the union of central and sublobular veins; the latter are easily identified by their thick walls and isolated position in the interlobular connective tissue. Into what vessels do the sublobular veins drain? Obtain a vivid conception of the complete course of the blood.

Are 'hepatic lobules' comparable to lobules of other glands? What are 'portal lobules'?

4. Gall bladder. In vertical sections, identify: mucosa; submucosa?; muscularis; serosa. Type of folded epithelium? Goblet cells? Mucous glands? Definite arrangement of muscularis? 


\section{CHAPTER XI. \\ THE RESPIRATORY SYSTEM.}

\section{A. Larynx.}

In a section of the larynx, note: type of epithelium; tunica propria; lymphoid cells; submucosa; type of gland; muscle; cartilages; more than one type of cartilage?

Vocal cords. Observe the type of epithelium; its close relation to the fibrous, elastic 'cords'; elastic cartilage?; submucosa?

B. Trachea, Bronchi and Bronchioles.

r. Trachea. Study transverse sections. Note: mucous membrane; type of epithelium; goblet cells; prominent basement membrane; character of tunica propria; submucosa; nature of its tracheal glands; adventitia containing tracheal cartilages; trachealis muscle.

2. Bronchus. Compare with trachea as regards: $e p i$ thelium; presence of cartilage plates; presence of muscularis mucose; abundance of glands; relation to pulmonary and bronchial blood vessels.

3. Bronchiole. Compare with bronchus as regards: epithelium; glands; cartilage; relative development of muscularis mucose; blood vessels.

\section{Lung.}

I. Bronchi and bronchioles are continued into respiratory, or terminal, bronchioles, with epithelia ranging from the low, 
columnar, ciliated type to flattened, non-ciliate, and nonglandular respiratory epithelium; the latter is partially composed of non-nucleated plates. Next in order are the alveolar ducts, having respiratory epithelium and scattered bundles of smooth muscle. Thence non-muscular atria are usually recognized, leading into the alveolar sacs, which terminate in pocket-like alveoli of respiratory epithelium.

Identify the above divisions, both in transverse and longitudinal section, and study their structure in detail. Understand thoroughly the histology of the alveoli and their relation to capillaries.

2. In vertical sections, identify and study: mesothelium and thin tunica propria of pulmonary pleura; subserous layer (fibro-elastic); interlobular septa; interalveolar septa.

3. Blood supply. Study injected sections, observing the profuse capillary net and its intimacy to the alveoli. Through sections and texts discover the complete pulmonary and bronchial circulations, giving special attention to the association of definite blood vessels with the various divisions of the respiratory tree. 
CHAPTER XII.

THE URINARY SYSTEM.

\section{A. Kidney.}

I. General architecture. In a longitudinal section of an entire kidney, identify: capsule; cortex; medulla; hilus leading into the renal sinus, which is lined by the pelvis and calyces; renal (Malpighian) pyramids, each projecting, as a renal papilla, into a calyx; renal columns (of Bertin) formed by the cortex dipping down between pyramids to the renal sinus; in cortex, the radially arranged pars radiata (medullary rays) alternating with the pars convoluta (labyrinths); in the pars convoluta, renal (Malpighian) corpuscles.

\section{Detailed structure.}

(a) Learn from preparations of uriniferous tubules isolated by teasing, and from reconstruction in texts, the size and shape of the various divisions and their order of sequence.

(b) Corlex. Study radial and tangential sections. Observe the capsule (constituent tissues?), numerous blood vessels, and the scanty interstitial tissue.

In the pars convoluta, note: renal corpuscle; its glomerulus (afferent and efferent vessels?); glomerular (Bowman's) capsule and its visceral and parietal epithelium; neck, its position and epithelial transition; proximal and distal convoluled tubules; arched collecting (junctional) tubules.

In the pars radiata, note: proximal convoluted tubules (spiral portion); ascending limb of Henle's loop; straight collecting tubules.

(c) Medulla. Study radial and tangential sections. 
Note: descending and ascending limbs of Henle's loop: Henle's loop; collecting tubules; papillary ducts.

(d) Compare the various tubules as regards: size; caliber of lumen; size and shape of cells; character and stainability of cytoplasm; basement membrane.

Examine proximal convoluted tubules for 'rodded' cytoplasm and state of preservation of free edge. How is the size of its lumen said to vary with functional activity?

How far into the medulla may Henle's loops dip? Is there any correlation between the position of Henle's loop in the medulla and of its renal corpuscle in the cortex? What is the correlation between the depth of position of Henle's loop and the length and disposition of its thin segment?

How abundant are renal corpuscles just beneath the kidney capsule? Relative size of afferent and efferent arterioles of glomeruli? Significance? Where are water and salts probably excreted? Where urea? Importance of a glomerulus at the very beginning of a renal tubule in light of its flushing function?

What constitutes a 'renal lobule'; or renculus, the anatomical unit of the kidney?

3. Blood supply. Study radial sections of injected kidney and text figures.

Identify: (a) Arteries - interlobar; arciform; interlobular; afferent and efferent arterioles of glomerulus; glomerular capillaries; artcriolce recte. What is a rete mirabile?

(b) Veins-capillaries of cortex and medulla; stellate; interlobular; arciform; venulc recle; interlobar.

\section{B. Ureter.}

Transverse sections. Note: folded mucosa; tunica propria; poorly demarked submucosa; muscularis; adventitia. 
Type of epithelium? Observe the intimate relation of the abundant capillaries to it; are any capillaries intra-epithelial? Glands? Number and arrangement of muscle coats? How do these differ in the upper and lower halves of the tube? Is there a tunica serosa? Explain.

Understand the gross and histologic relations between the ureter, renal pelvis, calyces, and papillary ducts.

\section{Bladder.}

I. Vertical sections. (The general appearance varies greatly with the degree of distension.) Identify similar coats as in the ureter.

Note: presence or absence of folds in the miucosa; binucleate epithelial cells?; epithelial pits or crypts?; glands?; solitary lymph nodules?; interlacing muscle bundles; can separate muscular coats be distinguished?; lunica serosa?

2. Distended bludder. Examine vertical sections for changes in the epithelium and muscularis. What has happened to the epithelial cells?

\section{Urethra.}

\section{Female urethra.}

Transierse sections. Identify: folded mucosa; tunica propria; broad submucosa containing many thin-walled ieins; muscularis. Is there an adientitia?

In detail. note: type of epithelium; urethral glands; nature of their secretion?; broad cenous channels in submucosa (corpus caiernosum) and extending into muscularis; number and arrangement of muscular coats. Is the female urethra erectile? With what portion only of the male urethra does the entire female urethra correspond?

2. Male urethra. This will be studied in connection with the penis (p. 65). 
CHAPTER XIII.

THE REPRODUCTIVE SYSTEM.

I. Male Genital Organs.

A. Testis.

I. General architecture. Study sections (preferably longitudinal) of an entire testis. Identify: tunica albuginea; tunica vasculosa; mediastinum, from which radiating septula divide the testis into lobules; within lobules convoluted seminiferous tubules, continuous with straight tubules which anastomose in the mediastinum to form the rete testis; ductuli efferentes; epididymis; ductus deferens?; blood vessels.

2. Detailed structure. Note: seminiferous tubules; their fibrous wall, basement membrane, and stratified epithelium; various strata in the latter exhibiting stages in spermatogenesis; sustentacular cells (of Sertoli) and the distinctive position, shape, and appearance of both cells and nuclei; interstitial cells in the connective-tissue stroma; their size, amount of cytoplasm and cytoplasmic inclusions (pigment granules, fat droplets, or rod-like crystalloids).

What is a cytogenic gland? How long are uncoiled seminiferous tubules? Do tubules branch, anastomose, or exhibit blind ends? How many tubules to a lobule? What functions are ascribed to the sustentacular cells? What to the interstitial cells?

\section{Spermatozoa.}

(a) Identify the head, neck, and tail. Shape of head on the flat and in profile? Relative length of head and tail? 
Length of spermatozoa? When and where do they first become motile? Rate of swimming? Orientation to ciliary currents?

(b) Living spermatozoa. Cut fresh epididymis (preferably of a dog) into small pieces and place in normal saline solution. Mount a drop of the mixture and examine. Observe motility and variations in vigor. Study the undulatory lashing of the tail.

4. Spermatogenesis. Developmental stages occur in order at successive levels from periphery to lumen of seminiferous tubules. Note: spermatogonia, next to basement membrane; primary spermatocytes (largest in size); secondary spermatocytes (about half size of preceding); spermatids (about half size of preceding); spcrmatozoa.

Which stages exhibit mitoses? Find several stages in the transformation of spermatids into spermatozoa. Homologize the various parts of a spermatozoön with the cellular constituents of an unchanged spermatid.

\section{B. Ductuli efferentes.}

Study sections of a lobule of the epididymis. Note: alternate groups of columnar cells (usually ciliated) and $\mathrm{cu}$ boidal cells (occasionally ciliated) producing an irregular lumen; acidophilic and clear cells and their distribution; vesicular masses of secretion?; distinct basement membrane; circular layer of smooth muscle; connective-tissue stroma. Are the cilia motile?

\section{Ductus epididymidis.}

In sections of ducts cut variously, observe: type of $e p i$ thelium; character of cytoplasm; matted cilia; basement membrane; circular muscle layer; connective-tissue stroma.

Compare with efferent ducts. Are the cilia motile? 
What effect has the secretion of the epithelium upon spermatozoa?

\section{Ductus deferens.}

Transverse sections. Note: mucosa; type of epithelium; absence of cilia; tunica propria; robust muscularis; number, arrangement, and relative thickness of muscle coats; adventitia.

How does the ampulla differ in structure from the duct proper?

\section{E. Seminal Vesicle.}

Vertical sections. Note: sacculations, honeycombed with epithelial pits and folds; mucosa; type of epithelium; glands?; tunica propria; muscularis; number and arrangement of muscular coats; adventitia.

Identify the contents of the lumen. What is the chief function of the seminal vesicle?

Compare the structure of the ejaculatory duct with that of the ductus deferens (ampulla) and seminal vesicle.

\section{F. Prostate.}

Vertical sections. Note: capsule continuous with a dense stroma; constituent tissues?; sacculated alveoli; type of epithelium?; prostatic concretions, their occurrence, size, and markings; how interpreted?

Nature of prostatic secretion? What constitutes semen? To which histologic type of gland (p. 45) does the prostate belong?

From sections or texts learn the structure of the bulbourethral glands. Probable function? Homologue in the female? 


\section{G. Penis and Male Urethra.}

\section{Corpus penis.}

(a) General topography. Study transverse sections. Identify: epidermis; corium; subcutaneous; panniculus adiposus?; corpora cavernosa penis; corpus cavernosum urethre (c. spongiosum); tunica albuginea; pectiniform septum; trabecula; blood vessels and spaces; urethra.

(b) Detailed structure. Composition of tunica albuginea? Number and arrangement of layers? Why is the septum called 'pectiniform'? Constituent tissues of trabecula? Location and characteristics of helicine arteries? Note the thick-walled blood vessels with localized intimal swellings, and the endothelium-lined venous spaces of the erectile tissue.

Understand the course of the blood in the flaccid and erect penis, and the mechanics of erection. Compare the penis and clitoris in structure.

(c) Male urethra. Note: mucosa; type of epithelium; urethral glands (of Littré); tunica propria and submucosa permeated by venous spaces of the erectile tissue; muscularis? tunica albuginea.

Learn the difference in the prostatic, membranous, and cavernous urethre as regards epithelium and muscularis. The entire female urethra corresponds to how much of the male urethra?

2. Glans penis. Note: Difference in the epithelium on the outer and inner surface of the prepuce; close adherence of the epithelium of the glans; glands of Tyson?; sensory corpuscles.

Gross relation of glans to corpus penis? 
II. Female Genital Organs.

\section{A. Ovary.}

r. General topography. Study sections of an entire ovary. Identify: hilus; cortex; germinal epithelium; tunica albuginea; follicles and their location; cortical stroma; corpus luteum?; corpus albicans?; medulla; medullary stroma; blood vessels.

2. Detailed structure.

(a) Cortex. Note: germinal epithelium; how different from ordinary mesothelium?; tunica albuginea and cortical stroma; their constituent tissues?; 'interstitial' cells?; primary and vesicular (Graafian) follicles; their distribution according to degree of development.

(b) Vesicular (Graafian) follicles. Study a maturing follicle. From without inward, note: theca folliculi; its fibrous tunica externa and vascular tunica interna; membrana propria; stratum granulosum; cavity, or antrum, containing liquor folliculi; cumulus öphorus; corona radiata; zona pellucida; ovum.

In ovum, observe: vitelline membrane?; cytoplasm, containing deutoplasm; nucleus; chromatin cords; nucleolus.

How many ova are present at birth? Is this number subsequently increased? How many mature in a life-time? Views regarding the origin of the zona pellucida and liquor folliculi? Views as to the mechanics of follicle rupture? Look for atretic follicles.

(c) Oögenesis. Search for stages illustrating follicular development. Study: (I) change in size and deutoplasm content of ova; (2) appearance and increase in thickness of zona pellucida; (3) change from a single layer of flattened or cubical follicular cells, through stages of solid, stratified, radiating epithelium, to the formation of a cumulus oöphorus 
and stratum granulosum by the accumulation of liquor folliculi; (4) arrangement of the loose stroma into the theca, with its two tunics.

With what stages in spermatogenesis do the ova seen correspond? What stage in spermatogenesis corresponds to the mature ovum and polar bodies?

(d) Medulla. Observe the loose stroma, absence of follicles, and abundant blood vessels.

3. Corpus luteum. In sections, identify: fibrous capsule; corpus hamorrhagicum; plicated zone of lutein cells cut into radial cords by vascular connective-tissue trabccula; size, shape, and character of lutein cells; their fat-vacuolated cytoplasm.

Origin and history of the components of the corpus luteum? Origin, structure, and fate of the corpus albicans? Do the corpus luteum verum and corpus luteum spurium differ histologically? Functions?

\section{B. Uterine Tube.}

I. Isthmus or ampulla. Transverse sections. Note: mucosa; plica; type of epithelium; areas of non-ciliated cells?; mucous cells or glands?; vascular tunica propria; does it contain smooth muscle?; muscularis; number and arrangement of its coats; adventitia; serosa?

Functions of cilia? Is a submucosa recognizable? May the muscular coat be considered a muscularis mucose? Compare part for part the uterine tube, ductus deferens, and ureter.

2. Infundibulum. Compare sections of the fimbriated end of the tube with the lower portion just studied. Relative development of lumen, plica, and muscularis? Do villi occur? Are the mucosa and serosa continuous at the infundibular margin? 


\section{Uterus.}

I. Resting uterus.

(a) General topography. Study transverse sections of an entire uterus of a child or lower mammal. Identify: lumen; mucosa (endometrium); its extreme thickness and glands; muscularis (myometrium); number and arrangement of the muscle coats; serosa (perimetrium).

Size of lumen in life? Is there a submucosa?

(b) Detailed structure. (Vertical sections of adult uterus.)

(a') Mucosa. Note: type of epithelium; ciliated areas?; tunica propria; its vascularity and highly cellular character; uterine glands; their shape and lining epithelium.

How do the glands of the corpus and cervix differ as regards shape and secretion? What are 'ovules of Naboth'? Function of the cervical glands during pregnancy?

(b') Muscularis. Distinguish the number, arrangement, and relative thickness of the poorly defined muscle coats. Propriety of the term 'stratum vasculare' for the middle layer? Can the inner coat be regarded as an hypertrophied muscularis mucosa?

(c') Serosa. Constituent tissues?

2. Menstruating uterus. Study vertical sections. Compare with normal uterus as regards: thickness of mucosa; condition of epithelium and tunica propria; enlargement of blood vessels and glands; hemorrhages, subepithelial and external.

Extent of destruction of the mucosa? Method of repair? Understand the stages of the menstrual cycle and the views regarding its significance. 


\section{Decidual Membranes.}

I. Decidua vera. Vertical sections of pregnant uterine wall. Observe the amnion and chorion lying on the decidua vera; the latter is divisible into a superficial compact and a deep cavernous layer.

Note: absence of uterine epithelium and glands in the compact layer; laterally stretched glands in the cavernous layer; decidual cells; their size, shape, and number of nuclei; their origin?; muscularis; size of muscle cells.

2. Decidua basalis and placenta. (Vertical sections.)

(a) General topography. Identify: in placenta fœtalis, amnion, chorion, chorionic villi (free and attached), intervillous blood spaces; in placenta uterina (decidua basalis), compact layer, septa, blood vessels, cavernous layer, glands?

(b) Detailed structure.

$\left(a^{\prime}\right)$ Observe under low magnification an immersed chorionic villus, noting its broad main stems and profuse terminal branches.

$\left(b^{\prime}\right)$ Chorionic villi in section. Observe: axial tissue and vessels; inner epithelial layer (of Langhans)?; outer syncytial layer; syncytial knots; canalized fibrin.

$\left(c^{\prime}\right)$ Decidua basalis. Follow directions for decidua vera above; in addition observe septa and their contents and attached chorionic villi.

3. Blood supply. Trace the course of maternal and fetal blood. What simple fact indicates that these do not mingle? Why is the absence of clotting in the intervillous spaces remarkable? What functions are ascribed to the chorionic syncytium? 


\section{E. Vagina.}

Vertical sections. Note: mucosa; ruge; type of epithelium; absence of glands; papilla; lymph nodules?; muscularis; number and arrangement of its coats, fibrous adventitia.

A loose, vascular layer deep in the tunica propria is sometimes regarded as a submucosa.

\section{F. Mammary Gland.}

This will be treated with the derivatives of the skin (p. 74). 


\section{CHAPTER XIV.}

\section{THE SKIN AND CUTANEOUS APPENDAGES.}

\section{A. Skin.}

I. General features. With a lens examine the volar surface of the index finger: Observe the sulci and crista and the rows of sweat gland pores on the latter. Compare the skin of the palm and dorsum of the hand and of the forearm.

2. Vertical sections (preferably of palmar or plantar surface).

(a) Epidermis. Identify: (I) stratum germinativum composed of a basal layer of columnar cells and of overlying, polygonal prickle cells; mitoses? (2) stratum granulosum, a double or triple row of coarsely granular, flattened cells; (3) stratum lucidum, a thin, clear layer with indistinct nuclei and cell boundaries; (4) stratum corneum, a thick, poorly staining layer of progressively flattened and cornified cells.

How does the skin of the general body surface differ from that of the palm or sole as regards the number of strata present and the thickness of each? Where is the pigment of a white brunette located? Of a negro? What is the histology of 'freckles' and of 'tan'? Views as to pigment origin? L.earn the chemical transformations accompanying the physical changes in the history of an epidermal cell.

(b) Corium or derma. Distinguish a poorly demarked, superficial papillary layer and a deep, looser and coarser reticular layer. What is the general direction of the interlacing fibers? 
In the papillary layer identify numerous conical papille bounded by a basement membrane and containing vascular loops or occasional tactile corpuscles.

(c) Subcutaneous. Identify bands of areolar tissue containing lobules of fat. Find here and in the deep corium sweat glands, sebaceous glands, hair follicles, and occasional lamellar corpuscles.

What constitutes a panniculus adiposus?

\section{B. Nails.}

I. General topography. Examine longitudinal and transverse sections. Identify: nail body overlying the longitudinally ridged nail bed and ending distally in the free edge, with its subjacent hyponychium; nail root, beginning at the lunula and nail groove (sulcus), with its overhanging eponychium, and extending proximally over the nail matrix.

\section{Detailed structure.}

(a) Nail root. Note: epidermal fold of the sulcus in which lies the nail plate; stratum germinativum; stratum granulosum? What layer does the nail plate represent? Which layer comprises the eponychium? Its extent into the sulcus? Explain the progressive thickening of the nail distad and the general method of nail growth. Extent and interpretation of the lunula?

(b) Nail body. Compare with the nail root. Relation of hyponychium to nail bed? Relation of nail plate to epidermal strata at lateral margins? Significance of the narrow light band seen just proximal to the free edge of a nail? Interpretation of white spots in the nail plate? Rate of nail growth? Are nails replaced after total removal? 


\section{Hair.}

I. General topography. In longitudinal sections, identify: shaft; root; bulb; follicle, consisting of an inner and outer epithelial root sheath and a connective-tissue sheath; papilla; angular insertion of hair; sebaceous glands; arrector muscles.

2. Detailed structure. Transverse and longitudinal sections. From without inward, note: connective-tissue sheath with an outer longitudinal, middle circular, and inner hyaline (i. e., basement membrane) layer; outer rool shealh, a continuation of the stratum germinativum; inner root sheath, with an outer Henle's layer (single row of non-nucleated celis), a middle Huxley's layer (two or three rows deep), and a culicle of cornified scales; hair, with an outer cuticle, middle cortex, and inconstant medulla.

Ascertain the structural differences at various levels from texts and longitudinal sections, and find corresponding transverse sections. Note especially the changes in the hair cuticle and cortex from shaft, through root, to bulb. Contents of the papilla? In light of its development homologize all layers of the hair follicle with unmodified skin.

Position of arrector muscles and sebaceous glands with respect to each other and to the angular insertion of the hair? Explain 'goose flesh.' What cells in the hair bear pigment? Causes of whitening of the hair? Method and rate of hair growth? Method and frequency of replacement? Will hairs forçibly removed be replaced?

\section{Sebaceous Glands.}

Longitudinal sections. Identify: fibrous shealh; basement membrane; alveoli; ducl; its relation to the hair fol- 
licle; shape and character of basal and central cells of alveoli; progressive stages in fatty, cellular degeneration.

What is the composition and use of sebum? Distribution of sebaceous glands? What are 'black heads' and 'wens'?

\section{Sweat Glands.}

I. General topography. Study vertical sections of skin. Observe: position and size of coiled, secreting fundus; size and course of $d u c t$; its point of entrance, with respect to papillæ, into the skin; epidermal portion of duct; pore.

2. Detailed structure. Note: connective-tissue sheath; basement membrane; smooth muscle fibers of fundus; type of epithelium of fundus; character of its cytoplasm; type of epithelium of duct in corium; structure of duct in epidermis; its pronounced spiral epidermal course.

Composition and use of sweat? Occurrence of modified sweat glands?

\section{E. Mammary Gland.}

I. General topography. Study vertical sections or text figures, through the nipple and underlying corpus. Identify: lobes; lobules; interlobular connective tissue and fat; alveoli; lactiferous ducts; lactiferous sinus; nipple; areola.

2. Active gland. In sections, note: interlobular and interalveolar connective tissue; alveoli; basement membrane; type of alveolar epithelium; its variations in form and fat droplet content; ducts and their contents.

If available, study osmic preparations, but in any case understand the secretory activity of the epithelium. Compare with a sebaceous gland. Is fat elaborated by the gland cells or merely transferred through them? What is said to help the fat droplets of milk remain in emulsion? 
What are 'witch milk' and 'colostrum'? Origin of 'colostrum corpuscles'?

To which histologic type (p. 45) does the mammary gland belong? Compare with sweat glands in development and structure. Significance? What are the areolar glands (of Montgomery)?

3. Resting gland. Compare with lactating gland as regards: adipose and connective tissue; glandular tissue and ducts; size and contents of their lumina. With the cessation of lactation do alveoli degenerate in part or merely shrink? Postclimacteric history? Structure of the male mamma? 



\section{INDEX.}

Adipose tissue, 22

Adult bone, 24

Aggregate lymph nodules, 36

Amitosis, 15

Amnion, 69

Anaphase, I 5

Anus, 52

Appendages, cutaneous, $7 \mathrm{I}$

Appendix, vermiform, $5 \mathrm{I}$

Areolar tissue, 21

Arteries, 34

tunica externa of, 34 intima of, 34 media of, 34

Arterioles, 33

\section{BASOPHILES, 27}

Bladder, 6 r

gall, 56

Blood, 26

crystals, 28

platelets, 27

stain, Jenner's, 28

Wright's, 28

supply of decidual membranes, 69 of kidney, 60

of liver, 55

of splcen, 39

vessels of digestive tube, 52

Bonc, 24

adult, 24

decalcified, long, 24

development, 25

ground, 24

marrow, 28

red, 28

yellow, 28

Bronchi, 57

Bronchioles, 57

Bud, taste, 48

CAPILlaRies, 33

Cardia, 4)
Cardiac muscle, 29

Cardio-esophageal junction, 49

Carotid gland, 42

Cartilage, 23

elastic, 24

fibro-, 24

hyaline, 23

Cell, 14

division, 14

liver, of salamander, 14

mast, 27

multipolar, of spinal cord, 3 I

nerve, 31

multipolar, 14

Purkinje, $3 \mathbf{I}$

pyramidal, $3 \mathrm{I}$

resting, I4

spinal ganglion, $3 \mathrm{I}$

squamous, 14

sympathetic ganglion, 3 I

Cement of teeth, 47

Chorion, 69

Chorionic villi, 69

Ciliated epithelium, 18

Circulatory system, 33

Colon, 5 I

Columnar epithelium, I6

Connective tissue, modified, 22

Corium, 7 I

Corpus luteum, 67

of stomach, 49

penis, 65

Crystals, blood, 28

Cubical epithelium, 16 stratificd, I8

Cutancous appendages, $7 \mathrm{I}$

Cytology, I 4

Decatcified long bone, 24

Decidua basalis, 69

vera, 69

Decidual membrane, $(x)$

Dentine, 47

Derma, 7 I 
Digestion, glands of, 52

Digestive system, 46 tube, 48

blood vessels of, 52 nerves of, 52

Ductless glands, 40

Ductuli efferentes, 63

Ductus deferens, 64 epididymidis, $6_{3}$

Duodenal glands, $5^{\mathrm{x}}$

Duodenum, 50

ELASTIC cartilage, 24 tissue, 21

Embryonic tissue, 20

Enamel of teeth, 47

Endocardium, 35

Endothelium, r6

Eosinophiles, 27

Epicardium, 35

Epidermis, $7 \mathrm{I}$

Epithelia, modified, I8

pseudostratified, 17

simple, 16

stratified, 17

Epithelial tissues, 16

Epithelium, ciliated, I8

columnar, I6

cubical, $\mathrm{x} 6$

glandular, 18

neuro-, 19

pigmented, r9

squamous, $\mathrm{r} 6$

stratified cubical, 18

squamous, $\mathrm{I} 7$

transitional, 17

Eponychium, 72

Erythroplastids, 26

Esophagus, 48

Female genital organs, 66 urethra, $6 \mathrm{r}$

Fibers, nerve, 32

myelinated, 32

Fibrin, 28 unmyelinated, 32

Fibro-cartilage, 24

Fibrous tissue, compact, 21 white, 22

loose, 20

Foliate papillæ, 48
Follicle, Graafian, 66

Fundus of stomach, 49

Gall bladder, 56

Ganglion cell, spinal, $3^{\text {I }}$

sympathetic, 3I

Gastric glands, 50

Genital organs, female, 66 male, 62

Gland, carotid, 42

ductless, 40

duodenal, $5 \mathrm{I}$

gastric, 50

hemolymph, 38

intestinal, $5 \mathrm{r}$

lymph, 37

mammary, 74

active, 74

resting, 75

mucous, 44

of digestion, 52

parathyreoid, 4I

parotid, 52

salivary, 52

sebaceous, 73

serous, 44

sublingual, 53

submaxillary, 53

suprarenal, $4 \mathrm{I}$

thymus, 40

thyreoid, 40

sweat, 74

Glandular epithelium, r8

Glans penis, 65

Graafian follicle, 66

Granules, Nissl, I4

Ground bone, 24

HAIR, 73

Heart, 35

Hemolymph gland, 38

Hemolymph-node, 38

Hyaline cartilage, 23

Hyponychium, 72

Hypophysis, 42

ILEUM, 5 I

Intestinal glands, $5^{\mathrm{I}}$ 
Intestine, large, $5 \mathrm{I}$ small, 50

Intracartilaginous ossification, 25 Intramembranous ossification, 25

JEJUNUM, 5 I

Jenner's blood stain, 28

KidNey, blood-supply of, 60 detailed structure, 59 general architecture, 59

LARGE intestine, 5I

Leukocytes, 26 large mononuclear, 27 polymorphonuclear, 27

Lingual papillæe, 47 tonsil, 37

I.jps, 46

Liver, 54

blood supply of, 55 cell of salamander, 14 detailed structure, 55 general architecture, 54

Long bone, decalcified, 24

Lungs, 57

Lymph gland, 37

nodules, 36

aggregate, 36 solitary, 36

vessels, 35

Lymphatic organs, 36

Lymph-node, 37

Lymphocytes, 27

Lymphoid tissue, diffuse, 36

MALE genital organs, 62 urethra, 6 i, 65

Mammalian ovum, I4

Mammary gland, 74 active, 74 resting, 75

Marrow, bone, 28 red, 28 yellow, 28

Mast cells, 27

Membranes, mucous, 44 serous, 44

Menstruating uterus, 68
Mesothelium, I6

Metaphase, I 5

Mitosis, 15

Mononuclear leukocytes, large, 27

Mucosa of duodenum, 50

of stomach, 49

Mucous glands, 44

membranes, 44

tissue, 20

Multipolar nerve cell, I4

Muscle, cardiac, 29

non-striate, 29

skeletal, 30

smooth, 29

striate, 29

Muscular tissues, 29

Myelinated nerve fibers, 32

Myocardium, 35

NAILS, 72

Nerve cells, 3I multipolar, I 4

fibers, 32 myelinated, 32 unmyelinated, 32

terminations, 32

Nerves of digestive tube, 52

Nervous tissues, $3 \mathrm{I}$

Neuro-epithelium, 19

Neutrophiles, 27

Nissl granules, 14

Node, hemolymph-, 38

lymph, -37

Nodes of Ranvier, 32

Nodules, lymph, 36

aggregate, 36

solitary, 36

Non-striate muscle, 29

OöGEnesis, 66

Oral cavity, 46

Ossification, intracartilaginous, 25 intramembranous, 25

Ovary, 66

Ovum, mammalian, I4

Oxyphiles, 27

Palate, soft, 48

Palatine tonsil, 37

I'ancreas, 54 
Papillæ, foliate, 48 lingual, 47

Parathyreoid gland, 4 I

Parotid glands, 52

Penis, 65 corpus, 65 glans, 65

Peyer's patches, 36

Pharyngeal tonsil, 37

Pigmented epithelium, I9

Pituitary body, 42

Placenta, 69

Platelets, blood, 27

Precapillaries, 33

Prophase, I5

Prostate, 64

Pseudo-stratified epithelia, I 7

Purkinje cell, 3I

Pyramidal cell, 3 I

RANVIER's nodes, 32

Rectum, 52

Red bone marrow, 28

Reproductive system, 62

Respiratory system, 57

Resting cell, I4

uterus, 68

Reticular tissue, 20

SALIVARY glands, 52

Sebaceous glands, 73

Seminal vesicle, 64

Serous glands, 44 membranes, 44

Skeletal muscle, 30

Skin, $7 \mathrm{I}$

Small intestine, 50

Smears, technic, 28

Smooth muscle, 29

Soft palate, 48

Solitary lymph nodules, 36

Spermatids, $\sigma_{3}$

Spermatocytes, $6_{3}$

Spermatogenesis, $6_{3}$

Spermatogonia, 63

Spermatozoa, 62

Spinal cord, multipolar cell of, 3 I ganglion cell, $3 \mathrm{I}$

Spleen, 38
Spleen, blood supply of, 39 detailed structure, 39 general architecture, 38

Squamous cell, I 4 epithelium, 16 stratified, I 7

Stain, Jenner's blood, 28 Wright's blood, 28

Staining, technic, 28

Stomach, 49 mucosa of, 49

Stratified epithelium, I7 cubical, I8 squamous, 18

Stratum germinativum, 7 I granulosum, $7 \mathbf{I}$

Striate muscle, 29

Sublingual glands, 53

Submaxillary glands, 53

Suprarenal gland, 4I

Sustentative tissues, 20

Sweat glands, 74

Sympathetic ganglion cell, 3 I

TAste bud, 48

Teeth, 46 cement of, 47 enamel of, 47

Telophase, I5

Testes, 62

Thymus gland, 40

Thyreoid gland, 40

Tissue, adipose, 22

areolar, $2 \mathrm{I}$

connective, 20 modified, 22

diffuse lymphoid, 36

elastic, $2 \mathbf{r}$

embryonic, 20

fibrous, compact, 2 I white, 22

loose, 20

mucous, 20

muscular, 29

nervous, $3 \mathrm{I}$

reticular, 20

Tongue, 47

Tonsils, 37

Trachea, 57

Transitional epithelium, I7

Tunica externa of arteries, 34 
INDEX.

Tunica intima of arteries, 34 media of arteries, 34

UNMYELINATED nerve fibers, 32

Ureter, 60

Urethra, 6r female, $6 \mathrm{I}$ male, $6 \mathrm{I}, 65$

Urinary system, 59

Uterine tube, 67

Uterus, 68

menstruating, 68

resting, 68
VAGINA, 70

Veins, 35

Venules, 33

Vermiform appendix, 5 I

Vesicle, seminal, 64

Villi, chorionic, 69 of duodenum, 50

WrIGHT's blood stain, 28

YELLOw bone marrow, 28 



\section{COLLEGETERTBORS}

PUBLISHED BY

\section{W.B.SAUNDER $\mathbb{C} O \mathbb{M} \mathbb{R} \mathbb{N} \Psi$}

West Washington Square

Philadelphia

\section{London: 9, Henrietta Street, Covent Garden}

\section{Prentrss Embryology}

Laboratory Manual and Text-Book of Embryology. By CHARLES W. Prentiss, A. M., Ph. D., formerly Professor of Microscopic Anatomy in the Northwestern University Medical School, Chicago. Large octavo of 400 pages, with 368 illustrations, many in colors. Cloth, $\$ 3.75$ net.

This rew work on Embryology is both laboratory manual and descriptive text-book. It is the only recent single volume describing the chick and pig embryos usually studied in the laboratory, giving you as well a concise, systematic account of human embryology. The descriptions of the chick and pig embryos to be studied in the laboratory cover over 100 pages and are illustrated with 132 instructive illustrations, most of them original.

Dr. J. W. Papez, Atlanta Medical College: "It is the only book that has fulfilled my needs cxactly. I am using the book this session and will continue to use it in the future."

\section{Herricks: Nerrology}

Introduction to Neurology. By C. Judson HerRick, Ph. D., Professor of Neurology in the University of Chicago. $12 \mathrm{mo}$ of 360 pages, with 137 illustrations. Cloth, $\$ 1.75$ net.

This work will help the student to organize his knowledge and to appreciate the significance of the nervous system as a working mechanism. It presents the actual inner workings of the nervous mechanisms in terms that he can understand at the very beginning of his course in psychology, general zuölogy, comparative anatomy, and general medicine. 


\section{McFarland's Biology}

Biology: General and Medical. By Joseph McFardand, M. D., Professor of Pathology and Bacteriology, University of Pennsylvania. I $2 \mathrm{mo}$ of 457 pages, illustrated. Cloth, $\$ \mathrm{r} .75$ net.

Just Issued. New (3d) Edition.

This work is particularly adaptable to the requirements of scientific courses. There are chapters on the origin of life and its manifestations, the cell and cell division, reproduction, ontogenesis, conformity to type, divergence, structural and blood relationship, parasitism, mutilation and regeneration, grafting, senescence, etc.

Prof. W. R. McConnell, Pennsylvania State College: "It has some admirable features, the most valuable of which is the careful résumé of the subjects of heredity and evolution."

\section{Drew's Inverrebrate Zoölogy}

Invertebrate Zoology. By Gilman A. Drew, Ph. D., Assistant Director of the Marine Biological Laboratory, Woods Hole, Mass. I2mo of $21_{3}$ pages. Cloth, $\$ 1.25$ net. New (2d) Edition.

Professor Drew's work gives the student a working knowledge of comparative anatomy and leads him to an appreciation of the adaptation of the animals to their environments. It is a practical work, expressing the practical knowledge gained through experience. The type method of study has been followed.

Prof. John M. Tyler, Amherst College: "It covers the ground well, is clear and very compact. The table of definitions is excellent."

\section{Daugherty's Economic Zoology}

Economic Zoölogy. By L. S. Daugherty, M. S., Ph. D., Professor of Science, Missouri Wesleyan College; and M. C. Daugherty. Part I-Field and Laboratory Guide: $12 \mathrm{mo}$ of 276 pages, interleaved. Cloth, $\$ \mathrm{r} .25$ net. Part II-Principles: $\mathbf{2 m o}$ of 406 pages, illustrated. Cloth, $\$ 2.00$ net.

Not only does this work give the salient facts of structural zoölogy and the development of the various branches, but also the natural history - the life and habits. It emphasizes the economic phase throughout.

Prof. V. E. Shelford, University of Chicago: "It has many merits and is the best book of the kind on the market." 


\section{Strles $\mathbb{N}$ urtritional PRysiology}

Vutritional Physiology. By Percy G. Stiles, Assistant Professor of Physiology at Harvard University. I 2 mo of 288 pages, illustrated. Cloth, \$r.25 net. Nerw (2d) Edition.

Dr. Stiles' new work takes up each organ, each secretion concerned in the process of digestion, discussing the part each plays in the physiology of nutrition-in the transformation of energy. In fact, the keynote of the book throughout is "energy"-its source and its conservation. The illustrations and homely similes are noteworthy.

Prof. M. E. Jaffa, University of California: "The presentation of the matter is excellent and can be understood by all."

\section{Sinles Nervous System}

The Nervous System and Its Conservation. By PERCY GoLDTHWAIT StIles, Assistant Professor of Physiology at Harvard University. $12 \mathrm{mo}$ of 230 pages, illustrated. Cloth, \$1.25 net.

Prof. Stiles' wonderful faculty of putting scientific things in language within the grasp of the non-medical reader is nowhere better illustrated than in this book. He has a way of conveying facts accurately with rifle-ball precision. This new book is really a physiology and anatomy of the nervous system, emphasizing the means of conserving nervous energy.

\section{Si̊les Human PRysiology}

IIuman Physiology. By Percy Goldthwait Stiles, Assistant Professor of Physiology at Harvard University. I $2 \mathrm{mo}$ of 400 pages, illustrated. Cloth, $\$ 1.50$ net.

This new physiology is particularly adapted for high and normal schools and general colleges. It presents the accepted facts concisely with only a limited description of the experiments by which these facts have been establiched. It is written by a teacher who has not lost the print of view of elementary students. Professor Stiles has a unique and forceful way of writing. He has the faculty of making clear, even to the unscientific reader. physiologic processes more or less difficult of comprchension. This he does by the use of happy teaching devices. The illustrations are as simple as the text. 


\section{Jordan's General Bacterrology}

General Bacteriology. By Edwin O. Jordan, Ph. D., Profecent of Bacteriology, University of Chicago. Octavo of 669 pages, illustrated. Cloth, $\$ 3.25$ net. Just Out-New (5th) Edition.

This work treats fully of the bacteriology of plants, milk and milk products, dairying, agriculture, water, food preservation; of leather tanning, vinegar making, tobacco curing; of household administration and sanitary engineering. A chapter of prime importance to all students of botany, horticulture, and agriculture is that on the bacterial diseases of plants.

Prof. T. J. Burrill, University of Illinois: "I am using Jordan's Bacteriology for class work and am convinced that it is the best text in existence."

\section{Eyye.s Bacteriologic Technic}

Bacieriologic Technic. By J. W. H. EYre, M. D., Bacteriologist to Guy's Hospital, London. Octavo of 525 pages, illustrated. Cloth, $\$ 3.00$ net.

Second Edition.

Dr. Eyre gives clearly the technic for the bacteriologic examination of water, sewage, air, soil, milk and its products, meats, etc. It is a work of much value in the laboratory. The illustrations are practical and serve well to clarify the text. The book has been greatly enlarged.

The London Lancet: "It is a work for all technical students, whether of brewing, dairying, or agriculture."

\section{Fred's Soill Bacteriology}

Soil' Bacteriology. By E. B. FRED, PH. G., Associate Professor of Agricultural Bacteriology, College of Agriculture, University of Wisconsin. I $2 \mathrm{mo}$ of 170 pages, illustrated. Cloth, $\$ 1.25$ net.

Dr. Fred has very carefully prepared a laboratory manual arranged primarily for students of soil bacteriology, soil chemistry, physics, and plant pathology. It is the outgrowth of many years' experience. The instructions he gives are unusually clear and definite, being based on quantitative results. He sets down a series of practical exercises on soil micro-organisms, on the nitrogen, carbon, sulphur, iron cycles, etc. 


\section{Hill's Norma! Histology}

Normal Hislology and Organography. By Charles Hitl, M. D., $12 \mathrm{mo}$ of 483 pages, 337 illustrations. Flexible leather, $\$ 2.25$ net.

New (3d) Edition.

Dr. Hill's work is characterized by a brevity of style, yet a completeness of discussion, rarely met in a book of this size. The entire field is covered, beginning with the preparation of material, the cell, the various tissues, on through the different organs and regions, and ending with fixing and staining solutions.

Dr. E. P. Porterfield, St. Louis University: "I am very much gratified to find so handy a work. It is so full and complete that it meets all requirements."

\section{Böhm, Davidoff, Hulber's Histology}

Histology. By A. A. BöнM, M. D., and M. von DAvipopr, M. D., of Munich. Edited by G. Carl Huber, M. D., Professor of Embryology at the Wistar Institute, University of Pennsylvania. Octavo of 528 pages, 377 illustrations. Flexible cloth, $\$ 3.5^{\circ}$ net.

Second Edition.

This work is conceded to be the most complete text-book on human histology published. Particularly full on microscopic technic and staining, it is especially serviceable in the laboratory. Every step in technic is clearly and precisely detailed. It is a work you can depend upon always.

New York Medical Journal: "There can be nothing but praise for this model text-book and laboratory guide."

\section{Keefer's Milizary Mygiene}

Military Hygiene and Sanilation. By Lreux.-CoL. Frank R. Kef.rer, Professor of Military Hygiene, United States Military Academy, West Point. 12 mo of 305 pages, illustrated. Cloth, \$e.50 net.

You get here chapters on the care of troops, recruits and recruiting, personal hygiene, physical training, preventable diseases, clothing, equipment, water-supply, foods and their preparation, hygiene and sanitation of posts, barracks, the troopship, marches, camps, and battlefields; disposal of wastes, tropic and arctic service, venereal diseases, alcohol, etc. 


\section{(O) wen's Treatment of Emergencies}

The Treatment of Emergencies. By Hubley R. Owen, M. D., Surgeon to the Philadelphia General Hospital. I 2 mo of 500 pages, with 249 illustrations.

Dr. Owen's book gives you not only the actual technic of the procedures, but also the reason why a particular method is advised. This makes for correctness. You get chapters on fractures of all kinds, on contusions and wounds, going fully into symptoms, treatments, and complications. Particularly strong is the chapter on gunshot wounds, which gives the new treatments that the great European War has developed. You get the principles of hemorrhage, together with its constitutional and local treatments. You get chapters on sprains, strains, dislocations, burns and scalds, etc. The book is complete; it is thorough; it is practical.

\section{Brady's Personal Health}

Personal Health. By William Brady, M. D., Elmira, New York. I $2 \mathrm{mo}$ of 407 pages. Cloth, $\$ 1.50$ net.

Just Issued.

Dr. Brady teaches you how to tako care of yourself, how to forestall illness, how to apply sound, practical judgment to the routine of your daily life. He gives you a clear idea of the causes of ill-health of any kind. He prescribes simple treatments when these are sufficient. He carefully indicates the stage at which professional advice should be sought. He knows what you want, for fifteen years' experience has taught him.

\section{Winslow's Prevention of Disease}

The Prevention of Disease. By KineLm Winslow, M. D., formerly Assistant Professor of Comparative Therapeutics, Harvard University. I 2 mo of 348 pages, illustrated. Cloth, $\$ 1.75$ net.

This book is a practical guide for the layman, giving him briefly the means to avoid the various diseases described. The chapters on diet, exercise, tea, coffee, and alcohol are of special interest, as are those on the prevention of cancer, colds, constipation, obesity, nervous disorders, tuberculosis, infantile paralysis, sex hygiene, decayed teeth, colds, enlarged tonsils and adenoids, and the diseases of middle age. The work is a record of twenty-five years' active practice. 


\section{Buchanan \& Murray's Backeriology}

Veterinary Bacteriology By Robert E. Buchanan, Ph. D., Professor of Bacteriology, and Charles Murray, B. SC., D. V. M., Associate Professor of Veterinary Bacteriology, Iowa State College of Agriculture and Mechanic Arts. Octavo of 590 pages, illustrated. Cloth, $\$ 3.50$ net. New (ad) Edition.

Professor Buchanan's new work goes minutely into the consideration of immunity, opsonic index, reproduction, sterilization, antiseptics, biochemic tests, culture media, isolation of cultures, the manufacture of the various toxins, antitoxins, tuberculins, and vaccines.

B. F. Kaupp, D. V.S., State Agricultural College, Fort Collins: "It is the best in print on the subject. . What pleases me most is that it contains all the late results of research."

\section{Sisson's Anatomy of Domestic Annimals}

A natomy of Domestic Animals. By Septimus Sisson, S. B., V. S., Professor of Comparative Anatomy, Ohio State University. Octavo of 930 pages, 725 illustrations. Cloth, $\$ 7.50$ net. New (2d) Edition.

Here is a work of the greatest usefulness in the study and pursuit of the veterinary sciences. This is a clear and concise statement of the structure of the principal domesticated animals-an exhaustive gross anatomy of the horse, ox, pig, and dog, including the splanchnology of the sheep, presented in a form never before approached for practical usefulness.

Prof. E. D. Harris, North Dakota Agricultural College: "It is the best of its kind in the English language. It is quite free from errors."

\section{Sharp's Vererinary Ophuthalmology}

Ophthalmology for Veterinarians. By Walter N. SharP, M. D., Professor of Ophthalmology, Indiana Veterinary College. I $2 \mathrm{mo}$ of 2 Io pages, illustrated. Cloth, $\$ 2.00$ net.

This new work covers a much neglected but important field of veterinary practice. Dr. Sharp has presented his subject in a concise, crisp way, so that you can pick up his book and get to "the point" quickly. He first gives you the anatomy of the eye, then examination, the various diseases, including injuries, parasites, errors of refraction.

Dr. George H. Glover, Agricultural Experiment Station, Fort Collins:

"It is the best book on the subject on the market." 


\section{Hadley on the Horse}

The Horse in Health and Disease. By Frederick B. Hadiey, D. V. M., Associate Professor of Veterinary Science, University of Wisconsin. I $2 \mathrm{mo}$ of 260 pages, illustrated. Cloth, \$1.50 net.

This new work correlates the structure and function of each organ of the body, and shows how the hidden parts are related to the form, movements, and utility of the animal. Then, in another part, you get a concise discussion of the causes, methods of prevention, and effects of disease. The book is designed especially as an introductory text to the study of veterinary science in agricultural schools and colleges.

\section{IKampps Poultiry Cunlturse}

Poultry Culture, Sanitation, anI Hygiene. By B. F. KAUpP, M. S., D. V. M., Poultry Investigator and Pathologist, North Carolina Experiment Station. I2mo of 4 I 7 pages, with I97 illustrations.

Cloth, $\$ 2.00$ net.

This work gives you the breeds and varieties of poultry, hygiene and sanitation, ventilation, poultry-house construction, equipment, ridding stock of vermin, internal parasites, and other diseases. You get the gross anatomy and functions of the digestive organs, food-stuffs, compounding rations, fattening, dressing, packing, selling, care of eggs; handling feathers, value of droppings as fertilizer, caponizing, etc., etc.

\section{Lynch's Diseases of Swine}

Diseases of Swine. With Particular Reference to Hog-Cholera. By Charles F. Lynch, M. D., D. V. S., Terre Haute Veterinary College. With a chapter on Castration and Spaying, by George R. Write, M. D., D. V. S., Tennessee. Octavo of 741 pages, illustrated. Cloth, $\$ 5.00$ net.

You get first some 80 pages on the various breeds of hogs, with valuable points in judging swine. Then comes an extremely important monograph of over 400 pages on hog-cholera, giving the history, causes, pathology, types, and treatment. Then, in addition, you get complete chapters on all other diseases of swine. 


\section{Lusks E Eements of $\mathbb{N}$ urtrition}

Elements of Nutrition. By Graham Lusk, Ph. D., Professor of Physiology, Cornell Medical School. Octavo of 402 pages, illus trated. Cloth, $\$ 3.00$ net.

Second Edition.

The clear and practical presentation of starvation, regulation of temperature, the influence of protein food, the specific dynamic action of food-stuffs, the influence of fat and carbohydrate ingestion and of mechanical work render the work unusually valuable. It will prove extremely helpful to students of animal dietetics and of metabolism generally.

Dr. A. P. Brubaker, Jefferson Medical College: "It is undoubtedly the best presentation of the subject in English. The work is indispenșable."

\section{Howel|'s PRysiology}

Physiology. By William H. Howgll, M. D., Ph. D., Professor of Physiology, Johns Hopkins University. Octavo of rozo pages, illustrated. Cloth, $\$ 4.00$ net.

New (6th) Edition.

Dr. Howell's work on human physiology has been aptly termed a "storehouse of physiologic fact and scientific theory." You will at once be impressed with the fact that you are in touch with an experienced teacher and investigator.

Prof. G. H. Caldwell, University of North Dakota: "Of all the textbooks on physiology which I have examined, Howell's is the best."

\section{Bergery's Hygiene}

Iygiene. By D. H. Bergey, M. D., Assistant Professor of Bac. teriology, University of Pennsylvania. Octavo of 529 pages, illustrated. Cloth, $\$ 3.00$ nct.

New (sth) Edition.

Dr. Bergey gives first place to ventilation, water-supply, sewage, industrial and school hygiene, etc. His long experience in teaching this subject has made him familiar with teaching needs.

J. N. Hurty, M. D., Indiana University: "It is one of the best books with which I am acquainted." 


\section{Pyle's Persona Hygiene}

Personal Hygiene. Edited by WAlter L. PyLe, MI. D., Fellow of the American Academy of Medicine. r2mo of 543 pages, illustraied. Cloth, \$1.50 net.

New (6th) Edition.

Dr. Pyle's work sets forth the best means of preventing disease-the best means to perfect health. It tells you how to care for the teeth, skin, complexion, and hair. It takes up mouth breathing, catching cold, care of the vocal cords, care of the eyes, school hygiene, body posture, ventilation, house-cleaning, etc. There are chapters on food adulteration (by Dr. Harvey $W$. Wiley), domestic hygiene, and home gymnastics.

Canadian Teacher: "Such a complete and authoritative treatise should be in the hands of every teacher."

\section{GaIbrañ}

Personal Hygiene and Physical Training for Women By Anna M. Galbraith, M. D. I 2 mo of 393 pages, illustrated. Cloth, $\$ 2.25$ net. New (2d) Edition.

Dr. Galbraith's book meets a need long existing - a need for a simple manual of personal hygiene and physical training for women along scientific lines. There are chapters on hair, hands and feet, dress, development of the form, and the attainment of good carriage by dancing, walking, running, swimming, rowing, etc.

Dr. Harry B. Boice, Trenton State Normal School: "It is intensely interesting and is the finest work of the kind of which I know."

\section{MaIenzie on Emercise}

Exercise in Education and Medicine. By R. TAlt McKenzin, M. D., Professor of Physical Fducation, University of Pennsylvania. Octavo of 585 pages, with 478 illustrations. Cloth, $\$ 4.00$ net. New (2d) Edition.

Chapters of special value in college work are those on exercise by the different systems: play-grounds, physical education in school, college, and university.

D. A. Sargent, M. D., Hemen way Gymnasium: "It should be in the hands of every physical educator." 


\section{Morrow's Care of Injursed}

Immediate Care of the Injured. By AlBert S. Morrow, M. D., Adjunct Professor of Surgery, New York Polyclinic. Octavo of 360 pages, 2.2 illustrations. Cloth, $\$ 2.50$ net. Second Edition.

Dr. Morrow's book tells you just what to do in any emergency, and it is illustrated in such a practical way t.rat the idea is caught at once. There is no book better adapted to first-aid class work.

Health: "Here is a book that should find a place in every workshop and factory and should be made a text-book in our schools."

\section{American Inlustrated Dictionary}

American Illustrated Medical Dictionary. By W. A. NewMAN Dorland, M. D., Member of Committee on Nomenclature and Classification of Diseases. American Medical Association. Octavo of 1137 pages, with 323 illustrations, Irg in colors. Flexible leather, $\$ 4.50$ net; thumb indexed, $\$ 5.00$ net. $N e w(81 /)$ Edition.

If you want an unabridged medical dictionary, this is the one you want. It is down to the minute; its definitions are concise, yet accurate and clear; it is extremely easy to consult; it defines all the newest terms in medicine and the allied subjects; it is profusely illustrated. John B. Murphy, M. D., Northwestern University: "It is unquestionably the best lexicon on medical topics in the English language, and with all that, it is so compact for ready reference."

\section{Anerican Pocket Dictionary}

American Pockel Medical Dictionary. Edited by W. A. NEWman Dorland, M. D. 693 pages. Flexible leather, \$1.25 net; thumb index, \$1.50 net.

New (olh) Edilion.

A dictionary must be full enough to give the student the information he seeks, clearly and simply, yet it must not confuse him with detail. The editor has kept this in mind in compiling this l'ocket I ictionary.

I. V. S. Stanislaus, M. D., Medico-Chirurgical College: "We have been strongly recommending this little book as being the very best."

DESCRIPTIVE CIRCULARS OF ALL BOOKS SENT FREE 




\section{Date Due}

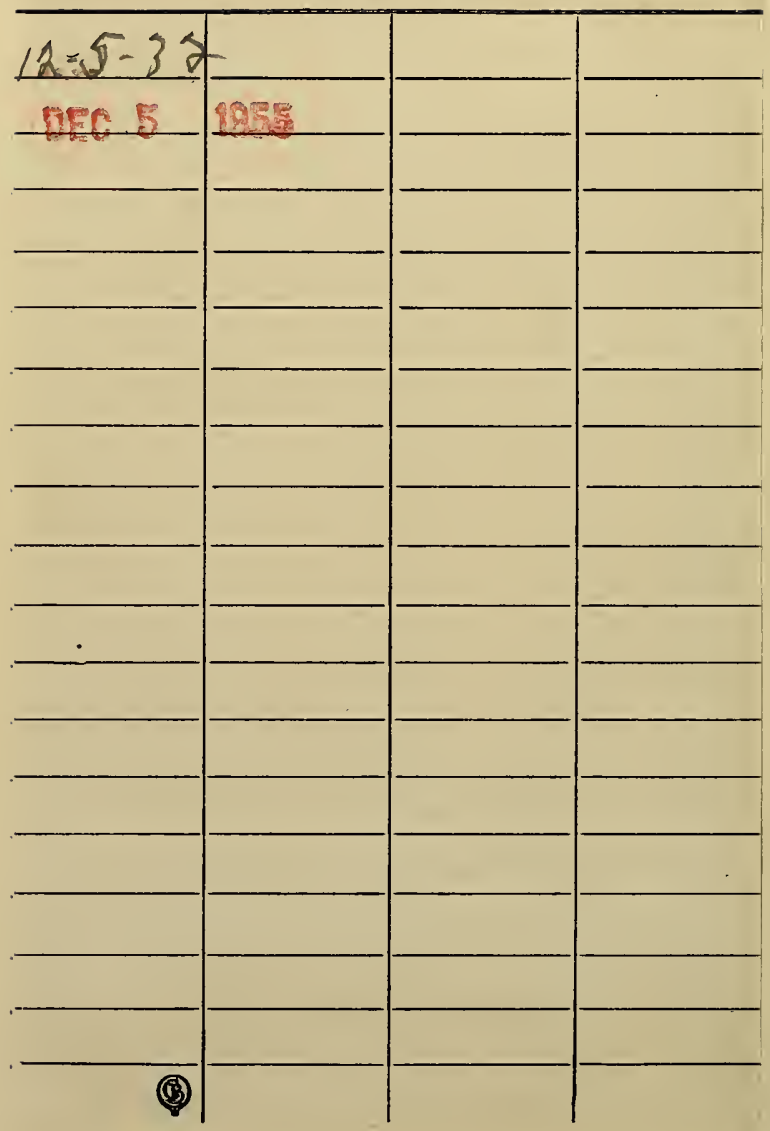


Q4555

Ar3

cop. 2

Arey

A laborátory guide in histology.

$$
\text { OEC } 5 \text { - 195EW. Stahl }
$$


